\title{
A marine origin for the late Mesoproterozoic Copper Harbor and Nonesuch Formations of the Midcontinent Rift of Laurentia
}

\author{
S.M. Jones ${ }^{a}$, A.R. Prave ${ }^{a}$, T.D. Rauba, J. Cloutier ${ }^{a, b}$, E.E. Stüeken ${ }^{a}$, C.V. Rose ${ }^{a}$, S. Linnekogel ${ }^{a}$, K. \\ Nazarov ${ }^{\mathrm{a}}$

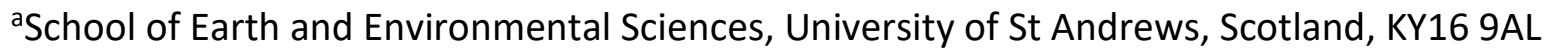 \\ ${ }^{b}$ Centre for Ore Deposits and Earth Science, University of Tasmania, Private Bag 79, Hobart, \\ Tasmania, Australia
}

Corresponding author: Simon Jones (smj5@st-andrews.ac.uk)

\begin{abstract}
The c. $1.1 \mathrm{Ga}$ Copper Harbor and Nonesuch formations of the Keweenawan Supergroup exposed along the Canadian-United States shorelines of Lake Superior are part of the surface exposures of the Laurentian Midcontinent Rift. These units have long been considered non-marine in origin and have figured prominently in ideas regarding the evolution of microbial life and the redox conditions of Earth's ocean-atmosphere system at the close of Mesoproterozoic time. However, these rocks also host hydrothermal metal deposits, the emplacement of which may have compromised primary geochemical signals that are used to underpin those ideas. Here we highlight new sedimentological observations to provide an independent framework for assessing the depositional setting and geochemistry of those strata. We show that the totality of sedimentological features leads to the conclusion that parts of the upper Copper Harbor Formation and the entirety of the Nonesuch Formation were deposited along tide- and waveinfluenced shorelines and in shallow-marine settings under evaporitic conditions. Evidence for this interpretation includes the abundance of flaser, wavy, linsen and pinstripe bedding, ubiquity of reactivation surfaces and mud drapes associated with all ripple forms, superposed sets of ripple cross-lamination showing bimodal (herring-bone) sediment transport directions, desiccation cracks and metre-scale hummocky cross-stratification. Further, evaporite fabrics and pseudomorphs after gypsum in the upper $200 \mathrm{~m}$ of the Copper Harbor Formation and in numerous stratigraphic positions within the Nonesuch Formation indicate that the water body was saline, not fresh. The emerging palaeogeographic image is one of a large, shallow-marine embayment with fringing sabkha-like shorelines. Ideas about late Mesoproterozoic biospheric evolution and Earth's surface redox and oxygenation that rely on the Nonesuch Formation and Copper Harbor stromatolites having been deposited within a lacustrine setting require reassessment.
\end{abstract}

Keywords: Midcontinent Rift, Keweenawan Supergroup, Copper Harbor Formation, Nonesuch Formation, lacustrine, Mesoproterozoic

\section{Introduction}

Between the early Palaeoproterozoic Great Oxidation Event and the Cryogenian Snowball Earth episodes, Earth's marine sedimentary record archives a protracted transformation from the anoxic, bacterial world of the Archaean to the oxygenated, metazoan world of the Phanerozoic. This transformation has invited hypotheses about the potential role of freshwater habitats in the origin and early diversification of complex life because these environments may have become hospitable early on in Earth history (e.g. Sánchez-Baracaldo et al. 2017; Parnell et al. 2015). However, few examples of lacustrine sedimentary rocks are preserved thus determining the environmental conditions in non-marine settings during this time has remained relatively elusive. 
The Keweenawan Supergroup, a c. 1.1 Ga volcanic-sedimentary succession exposed along the Canadian-USA shorelines of Lake Superior (Figs. 1, 2), has been identified as one of the rare windows into lacustrine conditions, based in part on geochemical characteristics (e.g. Cumming et al. 2013). These strata have played a pivotal role in assessing the oxygenation of Earth's atmosphere (Cumming et al. 2013; Slotznick et al. 2018; Mitchell and Sheldon 2016) and the complexity of the non-marine biosphere (Wellman and Strother 2015; Fedorchuk et al. 2016). This succession also hosts a world class sediment-hosted Cu system (Bornhorst and Williams 2013; Ho and Mauk 1996; Mauk and Heisham 1992) the emplacement of which involved extensive postdepositional hydrothermal fluid circulation. Although some primary biogeochemical signatures may not have been modified by those fluids, the validity of palaeoenvironmental interpretations based on those signatures requires independent geological support. Here we report new sedimentological observations that show that parts of the upper Copper Harbor Formation and all of the Nonesuch Formation were deposited in marine-influenced settings, which necessitate reinterpretation of the biogeochemical and micropaleontological data from these rocks.

\section{Geological background}

The Keweenawan Supergroup, which represents the exposed northern portion of the 2000km-long subsurface geophysical feature known as the Midcontinent Rift (Hinze et al. 1997; Ojakangas et al. 2001; Stein et al. 2018), is estimated from geophysical data to be as much as 30 $\mathrm{km}$ thick (Behrendt et al. 1988). Volcanic rocks comprise the initial 18-20 km of the Supergroup and the remainder is a mostly sedimentary succession, which is the focus of our work, in particular the Copper Harbor and Nonesuch formations (Fig. 2). The former is interpreted as a mostly conglomeratic braided-fluvial deposit (White and Wright 1960; Wolff and Huber 1973; Elmore 1984) and the latter is mostly dark shale and fine sandstone interpreted to be lacustrine (Elmore 1989; Suszek 1997). U-Pb zircon dates for the eruptive ages of the volcanic rocks in the Copper Harbor Formation and on the underlying Portage Lake Volcanics constrain deposition of the two units to between c. $1093-1085 \mathrm{Ma}$ (Swanson-Hysell et al. 2019 and references therein). A Re-Os isochron age of $1078 \pm 24 \mathrm{Ma}$ on shales from the lower part of the Nonesuch Formation (Cumming et al. 2013) in context with a U-Pb zircon date of $1085.57 \pm 0.25 \mathrm{Ma}$ (Fairchild et al. 2017) on the underlying Lake Shore Traps in the upper part of the Copper Harbor Formation place the timing of deposition of the Nonesuch Formation to c. $1080-1060$ Ma, immediately after the expansion of eukaryotic diversity (e.g. Beghin et al. 2017).

\subsection{Non-marine palaeoenvironments}

Most workers interpret the Copper Harbor-Nonesuch succession as a fluvial-to-lacustrine couplet (White and Wright 1960; Wolff and Huber 1973; Elmore 1983, 1984; Elmore et al. 1989; Suszek 1997; Ojakangas et al. 2001; Cumming et al. 2013). The 100 to $2000 \mathrm{~m}$ thick, overall finingupward succession of red, cross-bedded to massive, clast- and matrix-supported cobble conglomerate, pebbly sandstone and sandstone of the Copper Harbor Formation is clearly braided fluvial (Fig. 3). The Nonesuch Formation is a 50-200 m thick mostly grey, variably organic-rich, finegrained siliciclastic unit that, combined with thin stromatolitic intervals in the upper part of the Copper Harbor Formation, is inferred to record lacustrine settings.

The original workers who performed the detailed facies analysis on the upper Copper Harbor and Nonesuch rocks noted explicitly that many of sedimentological features in those formations were inconclusive in pinpointing either a lacustrine or a marine environment (Elmore 1983, 1984, 1989; Suszek 1997). Consequently, the geological evidence for a lacustrine depositional setting became reliant on two lines-of-reasoning: the first was that the Nonesuch strata and stromatolitic intervals in the upper Copper Harbor Formation must be non-marine because they are sandwiched between thick non-marine red beds (the overlying Freda and 
underlying Copper Harbor formations) and the second was that the position of those rocks several hundreds of kilometres into the interior of the Laurentian craton made it doubtful that they were part of a marine embayment (e.g. Ojakangas et al. 2001). Regarding the first line-of-reasoning, there are ample examples of braided rivers and alluvial fans that interfinger with marine bodies of water and encase marine sediment, exemplars include the fringing shorelines of the Gulf of California, Red Sea and Persian Gulf. Schumm (1968) highlighted that, prior to the evolution of bank-stabilising land plants, many pre-Phanerozoic fluvial systems were braided in character; such settings would have occurred across all latitudes and climatic regimes and were capable of delivering coarse detritus directly to coastal and nearshore marine zones worldwide. Hence, the presence of braided fluvial rocks above and below the Nonesuch Formation and Copper Harbor stromatolites does not imply a lacustrine setting for the rocks in between. Regarding the second line-of-reasoning, it is important to note that many modern intra-cratonic marine-influenced water bodies are located hundreds of kilometres from their associated open-marine shorelines: St Petersburg (Russia), the 700-km-long Gulf of Bothnia, western margin of Hudson Bay and 400-kmlong James Bay in Hudson Bay are 1400 km, 500 km, $800 \mathrm{~km}$ and $1300 \mathrm{~km}$, respectively, from their nearest open-marine shorelines. Inferred paleogeography of the basin therefore cannot be used to disprove a marine setting.

Regarding biogeochemical data, S:C ratios, sulphur isotopes and molecular biomarkers in the Nonesuch Formation would be consistent with deposition under marine conditions (Pratt et al. 1991; Hieshima and Pratt 1991; Imbus et al. 1992). However, Os isotope data from the Formation have been considered incompatible with the postulated Os composition of 1-billion-year-old seawater (Cumming et al. 2013). Given the volume of early-and late-stage diagenetic fluids that have moved through those rocks, as evident by several generations of pyrite, differing oxidation states of Fe- and Cu-bearing minerals, remobilised hydrocarbons, subaqueous (syneresis) cracks and abundant concretions (Figs. 4-6), it is conceivable that some geochemical records may be compromised. We present new sedimentological observations from the upper Copper Harbor and Nonesuch formations with the aim to provide independent evidence for assessing the depositional setting and geochemistry of this crucial palaeoenvironmental archive.

\section{Sedimentological observations}

More than 150 years of copper mining in the Keweenaw Peninsula region has resulted in several hundred drill cores through the Copper Harbor-Nonesuch formations; we studied 80 that contain the most complete sections of the Nonesuch Formation and the upper part of the Copper Harbor Formation. To complement the core data, we logged sections of the formations in exposures at Potato River, Presque Isle, Big Iron River, Nonesuch Mine, Eagle River and Horseshoe Bay (Fig. 1) and used those combined datasets to construct the stratigraphic framework shown on Figure 7. The datum for that framework is a surface that marks a facies change in the upper part of the Nonesuch Formation. This change is expressed Peninsula-wide and is pinpointed in core and outcrop as a contact separating an underlying succession of dm-thick beds of grey to reddish-grey, flat-laminated and shallow trough cross-bedded sandstone, shale and mudstone, in places arranged into many-metres-thick, thickening- and coarsening-upward cycles, from an overlying succession of rippled dark grey shale and thin-bedded grey sandstone. To aid correlations in the north-eastern part of the outcrop belt we also used the 'Marker Bed', a fine-grained marlmudstone unit containing abundant $\mathrm{mm}$ - to $\mathrm{cm}$-scale blebs of calcite, which constitutes one of the informal members mining company geologists have defined to subdivide the $\mathrm{Cu}$-bearing part of the lower Nonesuch Formation (Fig. 7).

\subsection{Upper Copper Harbor Formation stromatolite interval (Horseshoe Harbor)}


The upper part of the Copper Harbor Formation contains two stromatolitic-oncolitic-oolitic limestone-bearing intervals (Elmore 1983) that have received considerable attention because of their potential as indicators for Mesoproterozoic non-marine life (e.g. Fedorchuk et al. 2016). We examined one of those, Horseshoe Harbor (Fig. 1; the other occurrence is Dan's Point, c. $15 \mathrm{~km}$ further west), and there the limestones occur as lenses to laterally continuous beds that are many centimetres to several decimetres thick (Figs. 8-10). Bases and tops of the limestone layers are sharp: bases commonly drape across underlying surface irregularities and cobbles that were standing proud prior to calcium carbonate deposition, whereas tops are onlapped and buried by the overlying siliciclastic rocks. Stromatolites are laterally-linked, multi-digitate domal and hemispheric forms marked internally by sub-mm-thick crinkled-wrinkled laminae commonly separated by thin mud drapes and partings (Fig. 9A). In many places the stromatolites are broken, folded and brecciated (Fig. 9B). Detailed petrography by Fedorchuk et al. (2016) identified laminae formed by both biogenic and abiogenic (e.g. isopachus cements) calcium carbonate precipitation. The limestone layers are interbedded with patchily exposed reddish siltstone, sandstone and pebbly sandstone with calcium carbonate-filled desiccation cracks that penetrate downward for several to many centimetres (Fig. 9C-D).

All previous workers have noted the observations described above for the limestones. Here we highlight sedimentological features in the siliciclastic intervals that have received less attention but bear strongly on interpretations when placed within the context of the upper Copper HarborNonesuch succession. The key features are superposed ripple sets that display bimodal (herringbone) sediment transport directions and are marked by mud-drapes and reactivation surfaces (Fig. 10A-D). There are also dm-thick intervals of red mudstone that display well-preserved laminae arranged in $\mathrm{cm}$-thick stacked bundles of repetitively alternating thicker and thinner couplets implying a cyclical periodicity (Fig. 10E-F). Further, in instances where calcium carbonate layers lack microbial lamination and instead are characterised by massive or clotted textures, both the siliciclastic strata along the contact with those layers and the limestone layers themselves display isoclinal folding and warping (Fig. 9C-D).

\subsection{Uppermost Copper Harbor Formation}

In cores, as much as $\mathbf{2 0 0} \mathrm{m}$ of the upper Copper Harbor Formation consists of interbedded red conglomerate and sandstone and reddish-brown mudstone that contain abundant evaporitic fabrics and pseudomorphs (Fig. 11). Many conglomerate and sandstone intervals are calcrete marked by cobbles coated with $\mathrm{cm}$-thick rinds of calcite cement embedded within a calciteimpregnated matrix of poorly sorted silt to pebble grain sizes (Fig. 11A-B). The sandstones and mudstones are replete with $\mathrm{cm}$ - to dm-thick zones of chicken-wire fabric, closely spaced clots, nodules and stringers of calcite-pseudomorphed evaporite fabrics and caliche containing tepee structures, desiccation cracks and, in places, light grey $\mathrm{cm}$-thick micritic limestone and gypsum layers (Figs. 11C-H).

\subsection{Nonesuch Formation}

The Nonesuch Formation has been described in detail by a number of workers (Elmore 1989; Suszek 1997; Stewart and Mauk 2017). In brief, it is a succession of grey to black mudstone, shale and fine sandstone in beds from a few centimetres to many decimetres in thickness. Thin calcium carbonate beds punctuate the Formation, particularly in its lower part. Sedimentary features that have been documented previously include desiccation cracks, cm-scale wave and other ripple forms and microbially induced sedimentary structures (Figs. 12, 13).

What is striking about the Nonesuch rocks is the ubiquity of flaser, wavy, linsen and pinstripe bedding, combined-flow ripples, flat-topped symmetric ripples, climbing ripples, mud drapes and reactivation surfaces associated with all ripple forms, local presence of repetitively stacked sets 
and co-sets of bimodal (herring-bone) ripple cross lamination, metre- to decametre-scale thickening- and coarsening-upward depositional cycles and in places metre-scale hummocky crossstratification (Figs. 14, 15). The flaser-linsen-wavy-pinstripe ripples exhibit heights ranging from a few millimetres to as much as $5 \mathrm{~cm}$ and in almost all instances crests, troughs and individual foresets are outlined by mud drapes or encased in mudstone partings. Wavelengths for current and combined-flow ripple forms, as measured on bedding planes, range from $3 \mathrm{~cm}$ to as much as $10 \mathrm{~cm}$ whereas those for symmetric and flat-topped symmetric ripples are smaller, typically between $3 \mathrm{~cm}$ and $5 \mathrm{~cm}$. Further, ripple sets and co-sets in many places display repetitive patterns of thicker and thinner foresets in which the thicknesses of mudstone partings and drapes are inverse to the thickness of the sand-silt foresets and these are associated, both laterally and vertically, with dm-scale repetitions of pinstripe- to linsen- to wavy- to flaser-bedded ripples.

Although there is only one other report of the presence of syn-sedimentary evaporites in the Nonesuch Formation (gypsum laths in mudstone; see Fig. 4d in Elmore et al. 1989) there are an abundance of evaporite pseudomorphed minerals and fabrics present (Fig. 16). In the Nonesuch drill cores that we examined, these features were present at different stratigraphic levels and through the entirety of the Formation in the easternmost studied occurrences. They take the form of needles, laths, clots, nodules, blebs, clusters of nodules and as irregular blebs/clots arranged in discontinuous laminae. Sizes of all these forms vary from sub-mm to as much as several centimetres in diameter or length (Fig. 16).

\section{Discussion: marine-influenced sedimentation}

We combine our new sedimentological observations with previously reported ones to compare and contrast the abundance of sedimentary features known from lacustrine shoreline-littoralsublittoral zones to those from tide- and wave-influenced marine shoreline-shoreface-shelf settings (see Table 1). Although these environments share many of the same sedimentological features, we use the presence/absence of key features, combined with their commonality/paucity, to inform and guide our interpretation of the upper Copper Harbor and Nonesuch rocks. We conclude that the weight of evidence indicates a marine influence on the sedimentation of those strata.

\subsection{Features indicative of oscillatory or combined flows}

Wave periods of many seconds and associated horizontal orbital velocities of many $\mathrm{dm}^{*} \mathrm{~s}^{-1}$ to as much as $1 \mathrm{~m}^{*} \mathrm{~s}^{-1}$ or more are common in marine settings and known to be generated by storm events in large lakes. Their associated flows can mobilise and mould a spectrum of sedimentary structures across a wide range of grain sizes (e.g. bedform stability diagrams of Middleton and Southard 1984). These structures include symmetric and combined-flow ripples (ripples with symmetric form but marked internally by foresets migrating in one direction) and hummocky cross-stratification. The former two occur in both marine and lacustrine settings, although combined-flow ripples are more prevalent in marine settings hence their abundance in the Nonesuch Formation is noteworthy, however the presence of large-scale hummocky crossstratification in the Nonesuch Formation (Fig. 15A) is of particular significance.

Hummocky cross stratification (HCS) forms mostly in silt- and fine-sand-sized sediment under strong oscillatory flows (many tens of $\mathrm{cms}^{-1}$ ), with or without a weaker superimposed unidirectional component (e.g. Arnott and Southard 1990; Southard et al. 1990; Myrow and Southard 1996; Dumas et al. 2005). This process-product is attributed to sedimentation under storm waves acting on geostrophically driven storm-surge ebb flows that transport sediment from the shoreface across the shelf (Dott and Bourgeois 1982; Duke 1990; Duke et al. 1991). Central to that interpretation is that the spacings of hummocks scale to the horizontal diameters of wave- 
orbitals that penetrate downward through the water column to the seabed beneath the irregular (non-periodic, non-uniform) surface-gravity waves that typify a storm-generated sea state. This embodies the concept of the tempestite facies model (Ager 1974; Aigner 1982; Myrow and Southard 1996) whereby HCS is seen as part of a spectrum of storm-related features; sensu stricto, it is a bed of dm-scale thickness with a sharp, nearly flat base overlain by low-angle $\left(<15^{\circ}\right)$ intersecting sets of convex- and concave-up laminae arranged into domes (hummocks) and basins (swales) with spacings on the scale of metres and capped by wave ripples; laminae dip-directions are quaquaversal, reflecting the overall sculpting of the seabed into an irregular hummock/dome and swale/basin topography (Dott and Bourgeois 1982; Duke et al. 1990; Myrow 2005; although anisotropic aggradation can occur with a strong enough unidirectional flow component, e.g. Arnott and Southard 1990).

Hummock spacings of c. $1 \mathrm{~m}$ and larger are considered a key criterion for assigning a genesis to storm waves on a marine shelf (e.g. Duke et al. 1990; Myrow 2005). In contrast, lowangle convex-upward bundles of laminae having spacings on $\mathrm{dm}$-scales in siltstones and sandstones can form under a wide variety of combined oscillatory and unidirectional flow conditions, internal waves, scour-and-drape processes and short-term spatial-temporal contractions and expansions in flow thicknesses (e.g. Prave and Duke 1990; Prave 1990; Morsilli and Pomar 2012). The latter flow variations in particular can create hydraulic jumps between the lower-flow-regime subcritical states under which ripples form, and the upper-flow-regime critical states under which planar wavy laminae form and result in stacked sets of hummocky-wavy laminae intercalated with cross-lamination and ripple forms. Prave and Duke (1990) termed these features small-scale HCS, which are not diagnostic to any particular setting as evident by their recognition in facies ranging from abyssal turbidites (Prave and Duke 1990) to intertidal and shoreline sand bodies (e.g. Greenwood and Sherman 1986; Yang et al. 2006). Almost all HCS identified in lacustrine strata is small-scale HCS, i.e. wavy-parallel laminae with crest-to-crest spacings $<1 \mathrm{~m}$ and associated with intervals of wave or combined-flow ripples or scour-and-drape features (e.g. Andrews and Hartley 2015; Dam and Surlyk 1993; Eyles and Clark 1986; Greenwood and Sherman 1986; Ilgar and Nemec 2005; Jiang et al. 2018). In contrast, the HCS observed in outcrop of the Nonesuch Formation is identical to large-scale HCS recognised elsewhere that is unequivocally attributable to storm waves in inner-mid marine shelf settings, i.e. dm-thick fine sandstone beds with flat bases and characterised internally by hummocky cross-stratification with crest-to-crest spacings of 1-4 $\mathrm{m}$.

\subsection{Features indicative of periodically reversing or flashy (frequently accelerating-decelerating) flows}

Flaser, linsen, wavy and pinstripe bedding, reactivation surfaces and mud drapes, flat-topped wave ripples, bimodal (herring-bone) cross lamination and combined-flow ripples are hallmark features of sedimentation in shallow-marine settings. They reflect the frequent alternations in flow directions, flow accelerations and decelerations and associated changes in bed-generated shear stresses that mark tides and currents in marine shoreface-inner shelf settings. However, these sedimentary structures have also been reported from numerous ancient lacustrine settings where they can form by flashy fluvial discharge along shorelines and into the littoral zones of lakes as fluvial flow competency decreases via dissipation and flow expansion and via interactions with waves (e.g. Greenwood and Sherman, 1986; Ilgar and Nemec, 2005; Smith et al., 2015; Andrews and Hartley, 2015; O'Connell et al., 2017; Bright et al., 2018; Dorsey et al., 2018; Shchepetkina et al., 2019). In contrast to the discrete intervals in which such rippled facies are reported in lacustrine strata (op. cit.), what is striking about the Nonesuch Formation is the ubiquity of these ripple forms throughout its stratigraphy. This implies that the process by which they formed was 
similarly pervasive, which is a characteristic more readily attributable to marine than lacustrine settings.

\subsection{Periodically repetitive sedimentary structures}

Both the upper Copper Harbor and Nonesuch formations contain intervals in which sedimentary structures are present that display well-developed, periodically repetitive patterns or bundles of thinning and thickening of individual laminae or dm-thick rippled intervals. Foreset thicknesses and mudstone-to-sandstone ratios are inversely related, including instances showing systematic vertical change from pinstripe-linsen-wavy-flaser beds and vice versa. These features regularly occur interbedded with one another, indicating that they formed in settings with flows that fluctuated from being strong enough to generate shear stresses capable of transporting sandsized sediment to stagnant periods in which clays and muds settled out of the water column. Those fluctuations were short-lived, occurring on the temporal scale of laminae/ripple deposition and, further, many of these intervals also contain desiccation cracks. This eliminates varves as an interpretation of these repetitive features because varves form in the open, low-energy, deeper profundal portions of water bodies (e.g. Zolitschka et al. 2015). Consequently, the most straightforward interpretation of all of these rhythmic to periodically repetitive sedimentation patterns is as tidal bundles. Given that tidal currents are negligible even in the largest lakes (e.g. Lake Superior's tidal range is typically $5 \mathrm{~cm}$ or less; NOAA Great Lakes website) the environment of deposition of these strata is reasonably viewed as a tidally influenced marine shoreline-nearshore setting.

We have not determined periodicities of the Nonesuch tidal bundles to see if they match tidal spectra for $1 \mathrm{Ga}$ but such spectra require additional evidence to be conclusive. For example, Fourier transformations on laminae and foreset couplets preserved in the Neogene Bouse Formation, California, USA, yielded power spectra interpreted by some workers as daily-monthly tidal rhythmites (O'Connel et al. 2017) and by others as decadal-scale climatic lacustrine cycles (Bright et al. 2018). A tidal interpretation was confirmed by the presence of herring-bone cross strata (Dorsey et al. 2019). Sedimentological observations also underpin our interpretation of the periodically rhythmic features in the upper Copper Harbor and Nonesuch rocks as tidal bundles: they are interbedded with facies having desiccation cracks, herring-bone cross-lamination, abundant flaser bedding and wave- and combined-flow ripples.

\subsection{Evaporite minerals and oolites}

Oolites are not uncommon in lakes, hence their presence is inconclusive in differentiating between lacustrine and marine settings. In situations where freshwater has dissolved $\mathrm{Ca}^{+2}+\mathrm{Mg}^{+2}$ $>\mathrm{HCO}_{3}{ }^{-}$, and notwithstanding its generally low concentration of $\mathrm{S}$ species, gypsum precipitation (rather than Na-rich evaporates) can occur as lakes evaporate (Eugster and Hardie 1975; Smoot and Lowenstein 2000; Schreiber and El Tabakh 2000; Jagniecki and Lowenstein 2015); examples include the Miocene lake beds in the Ebro Basin, Spain (e.g. Orti et al. 2003), and the Triassic Passaic Formation in eastern USA (El-Tabkh et al. 1997). The presence of gypsum evaporites and pseudomorphs in the upper Copper Harbor and Nonesuch formations indicate clearly that their water bodies were more saline than freshwater. Combined with the sedimentological features with which they occur, the precipitation of these evaporite minerals and oolite formation from marine waters is the most likely scenario.

The upper Copper Harbor stromatolite intervals can also be inferred to have formed in saline water. The origin of intense folding exhibited by the limestone layers has puzzled previous workers (e.g. see discussions in Elmore 1983; Fedorchuk et al. 2016). We propose that the ptygmatically folded and broken limestones and similarly deformed laminae in the siliciclastic 
layers that encompass those limestones are, at least in part, enterolithic-style deformation due to the expansive growth and dissolution of former marine evaporite minerals. Storm waves are also a likely contributing factor to breaking and disrupting those beds. The caliche, calcrete and evaporite-mineral fabrics documented elsewhere in the upper Copper Harbor Formation are further evidence in support of widespread evaporative processes occurring at that time.

\subsection{Absence of depositional cyclicity}

In certain instances, the lack of key sedimentary features is worthy of note. In the case of the Nonesuch Formation, one of the striking aspects is the lack of widespread, laterally correlative and uniform metre-scale depositional cycles. Many ancient lacustrine settings are typified by such cycles, which record repetitive shallowing (marked by evaporite-bearing sediments) and deepening (marked by well-laminated fine-grained siliciclastic sediments) patterns attributed to Milankovitch-driven climatic forcing mechanisms (Eugster and Hardie 1975; van Houten 1962; Olsen 1986 [who termed these van Houten cycles]; Aswasereelert et al. 2013; Smith et al. 2015). Although the Nonesuch Formation has numerous stratigraphic intervals that indicate shallowing and deepening, the hallmark cyclicity of lakes is lacking. In our interpretation, these sedimentation patterns are readily explained by tides and other short-term changes in relative sea level (e.g. lateral migration of fluvial influx centres).

\section{Depositional setting}

The weight of evidence based on sedimentological observations (Table 1) leads us to conclude that the most direct and objective interpretation of the uppermost parts of the Copper Harbor Formation, including the stromatolitic intervals, is that they represent braidplains along an evaporitic shoreline under an arid climate and that the entirety of the Nonesuch Formation was a mostly shallow-marine, saline body of water that experienced both tide- and storm-influenced sedimentation. This implies a marine embayment large enough to reach well into the Laurentian craton and fringed with sabkha-like shorelines and caliche- and calcrete-bearing braidplains. Our interpretation is compatible with inferences that an arid climate prevailed during deposition of the Copper Harbor Formation (e.g. Wright 1960; Elmore 1983) and, given the evidence for abundant evaporite and desiccated mudstone facies in the Nonesuch Formation, it is likely that this climatic regime persisted through Nonesuch time. The lack of continuous outcrops of late Mesoproterozoic rocks beyond those fringing Lake Superior hinders efforts to determine the exact palaeogeography of this evaporitic shoreline-shallow marine embayment.

The widespread distribution of former evaporite fabrics and minerals, combined with the abundance of sedimentary structures that are attributable to tidal and shallow-marine settings, challenge ideas and hypotheses about non-marine habitats in the Proterozoic that rely on the Nonesuch Formation and Copper Harbor stromatolites having formed in a lacustrine environment. Our sedimentological findings show that the Nonesuch water body was saline, not fresh, and was shallow throughout much of its existence (abundance of desiccation cracks and strong- currentformed features) and these findings therefore require a reinterpretation of some existing geochemical datasets (e.g. Cumming et al. 2013). Our data also raise questions about the origin of the microfossils in the Nonesuch Formation (e.g. Wellman and Strother 2015; Strother and Wellman 2016); if the reported microfossils do indeed represent non-marine flora, they may have been transported from land environments via river systems and/or aeolian processes into the 
Table 1. The main sedimentary features identified in the upper Copper Harbor and Nonesuch formations classified by genesis and relative abundance in lacustrine shoreline-littoral-sublittoral zones ('lacustrine' column) and storm- and tide-influenced marine shoreline-shoreface-shelf settings ('marine' column). The features marked by a black-box ' $X$ ' are those we use to infer conclude that deposition occurred in a marine setting. Abundance criteria summarised from references cited in text and authors' own experience. See text for discussion

\begin{tabular}{|c|c|c|c|c|c|c|c|}
\hline \multirow{2}{*}{ process } & \multirow{2}{*}{ sedimentary feature } & \multicolumn{2}{|c|}{ common } & \multicolumn{2}{|c|}{ may be present } & \multicolumn{2}{|c|}{ rare to not present } \\
\hline & & lacustrine & marine & lacustrine & marine & lacustrine & marine \\
\hline \multirow{4}{*}{$\begin{array}{l}\text { unidirectional } \\
\text { flows }\end{array}$} & $\mathrm{dm}$-scale trough $\mathrm{x}$-bdg & $\mathrm{x}$ & $\mathrm{x}$ & & & & \\
\hline & dm-scale planar $x$-bdg & $\mathrm{x}$ & $\mathrm{x}$ & & & & \\
\hline & asymmetric ripples & $\mathrm{x}$ & $\mathrm{x}$ & & & & \\
\hline & climbing ripples & & & $\mathrm{x}$ & $\mathrm{x}$ & & \\
\hline \multirow{5}{*}{$\begin{array}{l}\text { oscillatory or } \\
\text { combined } \\
\text { flows }\end{array}$} & & & & & & & \\
\hline & combined-flow ripples & & $x$ & $\mathrm{x}$ & & & \\
\hline & symmetric ripples & $\mathrm{x}$ & $\mathrm{x}$ & & & & \\
\hline & small-scale HCS & & $x$ & $\mathrm{x}$ & & & \\
\hline & large-scale HCS & & $\mathrm{x}$ & & & $\mathrm{x}$ & \\
\hline & & & & & & & \\
\hline \multirow{5}{*}{$\begin{array}{l}\text { periodically } \\
\text { reversing or } \\
\text { flashy } \\
\text { (frequently } \\
\text { accelerating- } \\
\text { decelerating) } \\
\text { flows }\end{array}$} & $\begin{array}{l}\text { pinstripe-linsen-wavy- } \\
\text { flaser bedding }\end{array}$ & & $\mathrm{x}$ & $\mathrm{x}$ & & & \\
\hline & $\begin{array}{l}\text { ripple and foreset } \\
\text { mud drapes and } \\
\text { partings }\end{array}$ & & $\mathrm{x}$ & $\mathrm{x}$ & & & \\
\hline & $\begin{array}{l}\text { rhythmically repetitive } \\
\text { variations in laminae } \\
\text { thicknesses }\end{array}$ & & & $\mathrm{x}$ & $x$ & & \\
\hline & $\begin{array}{l}\text { repetitive bundles } \\
\text { showing systematic } \\
\text { variation in proportion } \\
\text { of sand and mud in } \\
\text { ripple sets and co-sets }\end{array}$ & & $\mathrm{x}$ & $x$ & & & \\
\hline & $\begin{array}{l}\text { bimodal (herring- } \\
\text { bone) sediment } \\
\text { transport }\end{array}$ & & & & $x$ & $\mathrm{x}$ & \\
\hline \multirow{3}{*}{$\begin{array}{l}\text { chemically } \\
\text { precipitated } \\
\text { minerals in } \\
\text { evaporitic } \\
\text { settings }\end{array}$} & limestones & & & $\mathrm{x}$ & $\mathrm{x}$ & & \\
\hline & oolites & & & $\mathrm{x}$ & $\mathrm{x}$ & & \\
\hline & $\begin{array}{l}\mathrm{Ca}-\mathrm{SO}_{4} \text { evaporites } \\
\text { (laths, nodules, clots, } \\
\text { chicken-wire) }\end{array}$ & & & $\mathrm{x}$ & $x$ & & \\
\hline \multirow{5}{*}{$\begin{array}{l}\text { other } \\
\text { features }\end{array}$} & $\begin{array}{l}\text { planar to wavy } \\
\text { laminated } \\
\text { sand/siltstones }\end{array}$ & $\mathrm{x}$ & $\mathrm{x}$ & & & & \\
\hline & $\begin{array}{l}\mathrm{m} \text { - to decameter-scale } \\
\text { thicken- and coarsen- } \\
\text { upward cycles }\end{array}$ & & $\mathrm{x}$ & $\mathrm{x}$ & & & \\
\hline & desiccation cracks & & & $x$ & $\mathrm{x}$ & & \\
\hline & $\begin{array}{l}\text { subaqueous } \\
\text { (syneresis) cracks }\end{array}$ & & & $\mathrm{x}$ & $\mathrm{x}$ & & \\
\hline & calcite concretions & & & $\mathrm{x}$ & $\mathrm{x}$ & & \\
\hline
\end{tabular}


Nonesuch marine embayment. If so, such re-sedimentation processes will need to be considered and evaluated in palaeobiological studies focussing on assessing life in marine versus non-marine settings in Precambrian successions elsewhere.

\section{Conclusions}

The long-held inference that the late Mesoproterozoic sedimentary strata exposed along the Canadian and USA shorelines of Lake Superior were totally non-marine is not supported by sedimentological data. Numerous features in the upper Copper Harbor Formation and throughout the Nonesuch Formation, ranging from herring-bone (bimodal) ripples to ubiquitous flaser-linsenwavy-pinstripe bedded intervals replete with reactivation surfaces, tidal bundles and desiccation cracks, to metre-scale hummocky cross stratification, to abundant evaporite fabrics and pseudmorphs after sulphate minerals, are most directly explained by a marine influence on sedimentation. Water composition throughout the deposition of these units was saline and the presence of networks of desiccation cracks at numerous stratigraphic levels in the Nonesuch Formation indicate that water depths were generally shallow for much of its sedimentation history. Instead of a fluvial-lacustrine couplet, the Copper Harbor-Nonesuch succession was a braided fluvial-evaporitic shoreline-marine embayment triplet. Consequently, ideas regarding biospheric evolution and Earth's surface redox and oxygenation state based on the premise that those sedimentary rocks were deposited within lacustrine settings require reassessment.

\section{Acknowledgements}

We thank First Quantum Minerals Ltd. and Highland Copper Company Inc. for supporting this work.

\section{Funding}

This work was supported by First Quantum Minerals Ltd., Vancouver, Canada.

\section{References}

Ager, D.V. 1974. Storm deposits in the Jurassic of the Moroccan High Atlas. Palaeogeography, Palaeoclimatology, Palaeoecology 15, 83-93.

Aigner T. 1982. Calcareous tempestites: storm-dominated stratification in Upper Muschelkalk limestones (middle Trias, SW-Germany). In: G. Einsele and A. Seilacher (eds.) Cyclic and Event Stratification. Springer, Berlin, Heidelberg, 180-198.

Andrews, S.D. and Hartley, A.J. 2015. The response of lake margin sedimentary systems to climatically driven lake level fluctuations: middle Devonian Orcadian Basin, Scotland.

Sedimentology 62, 1693-1716.

Arnott, R.W. and Southard, J.B. 1990. Exploratory flow-duct experiments on combined-flow bed configurations and some implications for interpreting storm event stratification: Journal of Sedimentary Petrology 60, 211-219.

Aswasereelert, W., Meyers, S.R., Carroll, A.R., Peters, S.E., Smith, M.E. and Feigl, K.L. 2013. Basinscale cyclostratigraphy of the Green River Formation, Wyoming. Geological Society of America Bulletin 125, 216-228.

Beghin, J., Storme, J.Y., Blanpied, C., Gueneli, N., Brocks, J.J., Poulton, S.W. and Javaux, E.J. 2017. Microfossils from the late Mesoproterozoic-early Neoproterozoic Atar/El Mreïti Group, Taoudeni Basin, Mauritania, northwest Africa. Precambrian Research 291, 63-82. 
Behrendt, J.C., Green, A.C., Cannon, W.F., Hutchinson, D.R., Lee, W.M., Milkereit, B., Agena, W.F. and Spencer, C. 1988. Crustal structure and deep rift basin of the Mid-continent Rift system--results from GLIMPCE deep seismic reflection profile. Geology 16, 81-85.

Bornhorst, T.J. and Williams, W.C. 2013. The Mesoproterozoic Copperwood sedimentary rockhosted stratiform copper deposit, Upper Peninsula, Michigan. Economic Geology 108, 1325-1346.

Bright, J., Cohen, A.S. and Starratt, S.W. 2018. Distinguishing brackish lacustrine from brackish marine deposits in the stratigraphic record: A case study from the late Miocene and early Pliocene Bouse Formation, Arizona and California, USA. Earth Science Reviews 185, 974-1003.

Cannon, W.F. and Nicholson, S.W. 2001. Geologic map of the Keweenaw Peninsula and adjacent area, Michigan. Misc. Investigation Series Map 1-2696. US Geological Survey.

Cannon, W.F., Nicholson, S.W., Woodruff, L.G., Hedgman, C.A. and Schulz, K.J. 1995. Geologic map of the Ontonagon part of the Wakefield 30' x 60' Quadrangle, Michigan. Misc. Investigation Series Map 1-2499. US Geological Survey.

Cannon, W.F., Woodruff, L.G., Nicholson, S.W. and Hedgman, C.A. 1996. Geologic map of the Ashland and the northern part of the Ironwood $30^{\prime} \times 60^{\prime}$ Quadrangles, Michigan. Misc. Investigation Series Map 1-2566. US Geological Survey.

Cumming, V.M., Poulton, S.W., Rooney, A.D. and Selby, D. 2013. Anoxia in the terrestrial environment during the late Mesoproterozoic. Geology 41, 583-586.

Dam, G. and Surlyk, F. 1993. Cyclic sedimentation in a large wave and storm-dominated anoxic lake; Kap Stewart Formation (Rhaetian-Sinemurian), Jameson Land, East Greenland. Special Publication of the International Association of Sedimentology 18, 419-448.

Dorsey, R.J., O’Connell, B., McDougall, K., Homan, M.B. 2018. Punctuated sediment discharge during early Pliocene birth of the Colorado River: evidence from regional stratigraphy, sedimentology, and paleontology. Sedimentary Geology 363, 1-33.

Dott, R.H., Jr. and Bourgeois J. 1982. Hummocky stratification: significance of its variable bedding sequences. Bulletin Geological Society of America 93, 663-680.

Duke, W.L. 1990. Geostrophic circulation or shelf turbidity currents: the dilemma of paleoflow patterns in storm-influenced prograding shoreline systems. Journal of Sedimentary Petrology 60, 870-883.

Duke, W.L., Arnott, R.W.C. and Cheel, R.J. 1991. Shelf sandstones and hummocky crossstratification: new insights on a stormy debate: Geology 19, 625-628.

Dumas, S., Arnott, R.W.C. and Southard, J.B. 2005. Experiments on oscillatory and combined-flow bed forms: implications for interpreting parts of the shallow marine sedimentary record. Journal of Sedimentary Research 75, 501-513.

El-Tabakh, M., Riccioni, R. and Schreiber, B.C. 1997. Evolution of late Triassic rift basin evaporites (Passaic Formation): Newark Basin, eastern North America. Sedimentology 44, 767-790.

Elmore, R.D. 1983. Precambrian non-marine stromatolites in alluvial fan deposits, the Copper Harbor Conglomerate, Upper Michigan. Sedimentology 30, 829-842.

Elmore, R.D. 1984. The Copper Harbor Conglomerate: a late Precambrian fining-upward alluvial fan sequence in northern Michigan. Geol. Soc. Amer. Bull. 95, 610-617.

Elmore, R.D., Milavec, G.J., Imbus, S.W. and Engel, M.H. 1989. The Precambrian Nonesuch Formation of the North American Mid-Continent Rift, sedimentology and organic geochemical aspects of lacustrine deposition. Precambrian Research 43, 191-213. 
Eugster, H.P. and Hardie, L.A. 1975. Sedimentation in an ancient playa-lake complex: the Wilkins Creek Member of the Green River Formation, Wyoming. Geological Society of America Bulletin 86, 319-334.

Eyles, N. and Clark, B.M. 1986. Significance of hummocky and swaley cross-stratification in late Pleistocene lacustrine sediments of the Ontario basin, Canada. Geology 14, 679-682.

Fairchild, L.M., Swanson-Hysell, N.L., Ramezani, J., Sprain, C.J. and Bowring, S.A. 2017. The end of Midcontinent Rift magmatism and the paleogeography of Laurentia. Lithosphere 9, 117-133.

Fedorchuk, N.D., Dornbus, S.Q., Corsetti, F.A., Isbell, J.L., Petryshyn, V.A., Bowles, J.A. and Wilmeth, D.T. 2016. Early non-marine life: evaluating the biogenicity of Mesoproterozoic fluviallacustrine stromatolites. Precambrian Research 275, 105-118.

Greenwood, B. and Sherman, D. 1986. Hummocky cross stratification in the surf zone: flow parameters and bedding genesis. Sedimentology 33, 33-46.

Hieshima, G.B. and Pratt, L.M. 1991. Sulfur/carbon ratios and extractable organic matter of the middle Proterozoic Nonesuch Formation, North American Midcontinent Rift. Precambrian Research 54, 65-79.

Hinze, W.J., Allen, D.J., Braile, L.W. and Mariano, J. 1997. The Midcontinent Rift system: a major Proterozoic continental rift, In: Ojakangas, R.W., Dickas, A.B. and Green, J.C. (eds.) Middle Proterozoic to Cambrian Rifting, Central North America. Geological Society of America Special Paper 312, 7-35.

Ho, E.S. and Mauk, J.L. 1996. Relationship between organic matter and copper mineralization in the Proterozoic Nonesuch Formation, northern Michigan. Ore Geology Review 11, 71-88.

Ilgar, A. and Nemec, W. 2005. Early Miocene lacustrine deposits and sequence stratigraphy of the Ermenek Basin, central Taurides, Turkey. Sedimentary Geology 173, 233-275.

Imbus, S.W., Macko, S.A., Elmore, D.R. and Engel, M.H. 1992. Stable isotope (C,S,N) and molecular studies on the Precambrian Nonesuch Shale (Wisconsin-Michigan, USA): evidence for differential preservation rates, depositional environment and hydrothermal influence. Chemical Geology 101, 255-281.

Jagniecki, E.A. and Lowenstein, T.K. 2015. Evaporites of the Green River Formation, Bridger and Piceance Creek Basins: deposition, diagenesis, paleobrine chemistry and Eocene atmospheric $\mathrm{CO}_{2}$. In: M.E. Smith, A.R. Carroll (eds.) Stratigraphy and Paleolimnology of Green River Formation, Western USA, Syntheses in Limnogeology 1, Springer, Dordecht, 277-312.

Jiang, Z., Wang, J., Fulthrope, C.S., Liu, L., Zhang, Y. and Liu, H. 2018. A quantitative model of paleowind reconstruction using subsurface lacustrine longshore bar deposits - an attempt. Sedimentary Geology 371, 1-15.

Martin-Bello, L., Arenas, C. and Jones, B. 2019. Lacustrine stromatolites: useful structures for environmental interpretation - an example from the Miocene Ebro Basin. Sedimentology, 1-36 doi: $10.1111 /$ sed.12577

Mauk, J.L. and Heishima, G.B. 1992. Organic matter and copper mineralization at White Pine, Michigan, USA. Chemical Geology 99, 189-211.

Middleton, G.V. and Southard, J.B. 1984. Mechanics of sediment movement: SEPM Short Course 3, 2nd Ed., 401 p. 
Mitchell, R.L. and Sheldon, N.D. 2016. Sedimentary provenance and weathering processes in the 1.1 Ga Midcontinent Rift of Keweenaw Peninsula, Michigan, USA. Precambrian Research 275, 225240.

Morsilli, M. and Pomar, L. 2012. Internal waves vs. surface storm waves: a review on the origin of hummocky cross-stratification. Terra Nova 24, 273-282.

Myrow, P. 2005. Storms and storm deposits. Encyclopedia of Geology, 580-587.

Myrow, P. and Southard, J.B. 1996. Tempestite deposition. Journal of Sedimentary Research 66, 875-887.

O'Connell, B., Dorsey, R.J., Humphreys, E.D. 2017. Tidal rhythmites in the southern Bouse Formation as evidence for post-Miocene uplift of the lower Colorado River corridor. Geology 45, 99-102.

Ojakangas, R.W., Morey, G.B. and Green, J.C. 2001. The Mesoproterozoic Midcontinent Rift System, Lake Superior region, USA. Sedimentary Geology 141-142, 421-442.

Olsen, P.E. 1986. A 40-million-year lake record of early Mesozoic orbital climatic forcing. Science 234, 842-848.

Ortí, F., Rosell, L. and Anadón, P. 2003. Deep to shallow lacustrine evaporites in the Libros Gypsum (southern Tereuk Basin, Miocene, Spain): an occurrence of pelletal gypsum rhythmites. Sedimentology 50, 361-386.

Parnell, J., Spinks, S., Andrews, S., Thayalan, W. and Bowden, S. 2015. High Molybdenum availability for evolution in a Mesoproterozoic lacustrine environment. Nature communications 6 , 6996, 1-6 DOI: 10.1038/ncomms7996

Pratt, L.M., Summons, R.E. and Hieshima, G.B. 1991. Sterane and triterpane biomarkers in the Precambrian Nonesuch Formation, North American Midcontinent Rift: Geochimica et Cosmochimica Acta 55, 911-916.

Prave, A.R. 1990. Clarification of some misconceptions about antidune geometry and flow character. Sedimentology 37, 1049-1052.

Prave, A.R. and Duke, W.L. 1990. Small-scale hummocky cross-stratification in turbidites: a form of antidune stratification? Sedimentology 37, 531-539.

Sánchez-Baracaldo, P., Raven, J.A., Pisani, D. and Knoll, A.H. 2017. Early photosynthetic eukaryotes inhabited low-salinity habitats. Proceedings National Academy of Sciences 114, E7737-E7745.

Schreiber, B.C. and El Tabakh, M. 2000. Deposition and early alteration of evaporites.

Sedimentology 47, 215-238.

Schumm, S.A. 1968. Speculations concerning paleohydrologic controls on terrestrial vegetation. Geol. Soc. Of Amer. Bull. 79, 1573-1588.

Shchepetkina, A., Gingras, M.K., Mángano, M.G. and Buatois, L.A. 2019. Fluvio-tidal transition zone: terminology, sedimentological and ichnological characteristics and significance. Earth Science Reviews 192, 214-235.

Slotznick, S.P., Swanson-Hysell, N.L. and Sperling, E.A. 2018. Oxygenated Mesoproterozoic lake revealed through magnetic mineralogy. Proceed. Nat. Acad. Sciences USA 115, 12938-12943.

Smith, M.E., Carroll, A.R. and Scott, J.J. 2015. Stratigraphic expression of climate, tectonism and geomorphic forcing in an underfilled lake basin: Wilkins Creek Member of the green River 
formation. In: M.E. Smith, A.R. Carroll (eds.) Stratigraphy and Paleolimnology of Green River Formation, Western USA, Syntheses in Limnogeology 1, Springer, Dordecht, 61-102.

Smoot, J.P. and Lowenstein, T.K. 1991. Depositional environments of non-marine evaporites. In: Evaporites, Petroleum and Mineral Resources (J.L. Melvin, ed.), Developments in Sedimentology 50, 189-347

Southard, J.B., Lambie, J.M., Fedemco, D.C., Pine, H.T. and Weidman, C.R. 1990. Experiments on bed configurations in fine sands under bidirectional purely oscillatory flow, and the origin of hummocky cross-stratification: Journal Sedimentary Petrology 60, 1-17.

Stein, S., Stein, C.A., Elling, R., Kley, J., Keller, G.R., Wysession, M., Rooney, T., Frederiksen, A. and Moucha, R. 2018. Insights from North America's failed Midcontinent Rift into the evolution of continental rifts and passive continental margins. Tectonophysics 744, 403-421.

Stewart, E.K. and Mauk, J.L. 2017. Sedimentology, sequence-stratigraphy, and geochemical variations in the Mesoproterozoic Nonesuch Formation, northern Wisconsin, USA. Precambrian Research 294, 111-132.

Strother, P.K. and Wellman, C.H. 2016. Palaeoecology of a billion-year-old non-marine cyanobacterium from the Torridon Group and Nonesuch Formation. Palaeontology 59, 89-108.

Suszek, T. 1997. Petrography and sedimentation of the Middle Proterozoic (Keweenwan) Nonesuch Formation, western Lake Superior region, Midcontinent Rift System. In: Ojakangas, R.W., Dickas, A.B. and Green J.C. (eds.) Middle Proterozoic to Cambrian Rifting, Central North America. Geol. Soc. Amer. Spec. Paper 312, 195-210.

Swanson-Hysell, N.L., Ramezani, J., Fairchild, L.M. and Rose, I.R. 2019. Failed rifting and fast drifting: Midcontinent Rift development, Laurentia's rapid motion and the driver of Grenvillian orogenesis. Geological Society of America Bulletin 131, 913-940.

Van Houten, F.B. 1962. Cyclic sedimentation and the origin of analcime-rich upper Triassic Lockatong Formation, west-central New Jersey and adjacent Pennsylvania. American Journal of Science 260, 561-576.

Wellman, C.H. and Strother, P.K. 2015. The terrestrial biota prior to the origin of land plants (embrophytes): a review of the evidence. Palaeontology 58, 601-627.

White, W.S. and Wright, J.C. 1960. Lithofacies of the Copper Harbor conglomerate, northern Michigan. U.S. Geological Survey Prof. Paper 400-B, 5-7.

Wolff, R.G. and Huber, N.K. 1973. The Copper Harbor Conglomerate (Middle Keweenawan) on Isle Royale, Michigan, and its regional implications. US Geological Survey Prof. Paper 754-B, 15 p.

Yang, B., Dalrymple, R.W. and Chun, S., 2006. The significance of hummocky cross-stratification (HCS) wavelengths: evidence from an open-coast tidal flat, South Korea. Journal of Sedimentary Research, 76(1), pp.2-8.

Zolitschka, B., Francus, P., Ojala, A.E.K. and Schimmelmann, A. 2015. Varves in lake sediments - a review. Quaternary Science Reviews 117, 1-41.

\section{Figure captions}

Figure 1. Simplified geological maps of the Lake Superior area, top, and Keweenaw Peninsula, bottom (after Cannon and Nicholson 2001; Cannon et al. 1995, 1996). 
Figure 2. Generalised stratigraphic framework of the geology of the Keweenaw Peninsula and adjacent areas. Age constraints from ${ }^{1}$ Fairchild et al. (2017), ${ }^{2}$ Swanson-Hysall et al. (2019) and ${ }^{3}$ Cumming et al. (2014).

Figure 3. Braided-fluvial features of the Copper Harbor Formation. A. Metres-thick massive cobble-boulder conglomerate at Horseshoe Harbor. B. Clast-supported cobble-boulder conglomerate and pebbly sandstone interbeds at Eagle River Falls; note clast imbrication $(20 \mathrm{~cm}-$ long notebook is aligned with imbrication). C. Small-scale, trough cross-bedded, coarse to pebbly sandstone interbedded with fining-upward cobble conglomerate lenses at Potato River Falls $(9 \mathrm{~cm}$ long scale bar). D. Cobble conglomerate with imbricated clasts at Potato River Falls; majority of clasts are felsic volcanic rocks with minor quartzite, granitoid gneiss and mafic igneous clasts $(12 \mathrm{~cm}$-long pen for scale is circled). E. Sharp-based sandy and carbonate-cemented matrixsupported conglomerate interbedded with flat- to low-angle laminated sandstone at 255-251 m depth in core WP-345 (68-64 m below base Nonesuch Formation). F. Interbedded red-brown mudstone and cross-bedded feldspathic litharenite at $204 \mathrm{~m}$ depth in core WP-345 (17 m below base Nonesuch Formation). G. Feldspathic litharenite with brown mudstone partings at $215 \mathrm{~m}$ depth in core WP-345 (28 m below base Nonesuch Formation); white arrows point to desiccation cracks and many mudstone partings recovered in this core display crinkled-wrinkled laminae and roll-up structures typical of microbial lamination; white bar is c. $10 \mathrm{~mm}$ for scale.

Figure 4. Diagenetic fluid-flow features in the Nonesuch Formation. A. Late pyrite crystals growing across calcite-pseudomorphed evaporite nodules (core JBY-002 depth $121.6 \mathrm{~m} ; 5.8 \mathrm{~m}$ above base of Formation). B. Native $\mathrm{Cu}$ in calcite-pseudomorphed evaporite nodules, pellets and syneresis crack (core WP-436 depth 250.3 m; 0.95 m above base of Formation). C. Pre-compactional early pyrite crystal replacing cauliflower-shaped calcite pseudomorphed evaporite nodule; cross-cutting veins are calcite (core WP-224 depth $28.6 \mathrm{~m} ; 13.8 \mathrm{~m}$ above base of Formation). D. Native Cu vein cutting chalcocite-rich laminae (core WP-126 depth $644.3 \mathrm{~m} ; 0.41 \mathrm{~m}$ above base of Formation). E. Early chalcocite formed in situ and reworked as infill in desiccation cracks (core WP-398 depth 727.9; $0.18 \mathrm{~m}$ above base of Formation). F. Remobilised hydrocarbons forming pyrobitumen vein network (20 m above base of Big Iron River section). White bars in are c. $10 \mathrm{~mm}$ for scale.

Figure 5. Diagenetic fluid-flow features in the Nonesuch Formation. A. Early calcite concretion cut by desiccation cracks ( $24.5 \mathrm{~m}$ above base of Big Iron River section). B. Pre-compaction/lithification network of calcite concretions (23 $\mathrm{m}$ above base of Big Iron River section). C. Abundant early formed calcite concretions in bedding-plane view (24 m above base of Big Iron River section). D. Late calcite concretion cutting across laminae (17 m above base of Big Iron River section). E. Chloritised concretion cutting dark-grey shale with abundant blebs of calcite-pseudomorphed evaporites; ghost laminae present in middle part of concretion (core JBY-002 core depth $113.6 \mathrm{~m}$; $41.6 \mathrm{~m}$ above base of Nonesuch Formation); white bar is c. $10 \mathrm{~mm}$ for scale.

Figure 6. Subaqueous (syneresis) cracks in siltstones and very fine sandstones of the Nonesuch Formation, note that most are bound with calcite cement. A-B. Irregularly shaped and spaced (bifurcating and bird-foot shapes) versus more regularly spaced and aligned to branching cracks; note that in B the calcite-cement filled cracks are cut by mud-filled desiccation cracks attesting to the former's syn-depositional formation. C. Ptygmatically folded subaqueous cracks in crosssection view; note upward and downward tapering of the cracks, as well as bowing of laminae at many crack tips. D. Line drawing of C. Examples A-D, and many others like them, occur from C. 2 to $30 \mathrm{~m}$ above the base of the Big Iron River section. 
Figure 7. Stratigraphic cross-section of the Nonesuch Formation illustrating key outcrop sections and cores. See Figure 1 for locations and text for discussion.

Figure 8. Logged section of Horseshoe Harbor stromatolite-bearing interval in the upper Copper Harbor Formation. Numbers to left of column are keyed to photographs in Figures 9 and 10. See Figure 1 for location and text for discussion.

Figure 9. Horseshoe Harbor stromatolitic limestones. A. Stromatolite mound growing upward off a cobble conglomerate bed; note numerous mud partings between laminae. B. Broken and brecciated stromatolite layer; note tepee-like and thrusted geometries for some of the fragments. c. Tightly folded calcite-filled desiccation crack; white arrows point to pale green coloured reduction spots and fracture surfaces. $\mathbf{D}$. Line drawing of $\mathbf{C}$. The calcite-filled desiccation crack is shaded a darker grey. Calcium carbonate layers that lack stromatolitic/microbial textures or laminae and instead display clotted to massive textures are shown in lighter grey; their growth has caused disruption and folding of lamination in the adjacent siliciclastic layers. See text for discussion and Figure 8 for locations of features within the stratigraphy.

Figure 10. Tide-influenced sedimentary structures in Horseshoe Harbor siliciclastic rocks. A-D. Photographs and associated line drawings of linsen and flaser bedded sandstone exhibiting superposed bimodal (herring-bone) sediment transport directions and abundant reactivation surfaces and laminae with mud drapes; planar cross-bedded sand-waves with reactivation surfaces cap the succession in A. E-F. Bundles of repetitively varying thick-thin laminae couplets (d.c. - desiccation crack); grey region at base of photo outlines micrite nodules and clots, likely calcite pseudomorphs of precursor evaporites. See text for discussion and Figure 8 for locations of features within the stratigraphy.

Figure 11. Evaporite fabrics and features in the uppermost Copper Harbor Formation. A-B. Calcrete and caliche conglomerate (A - core JBY-002 depth 164-162 m, 37-35 m below base of Nonesuch Formation; B - core WP-345 depth 276 m, 89 m below base of Nonesuch Formation). C. Zones of caliche, calcite-pseudomorphed evaporite nodules and chicken-wire fabrics in fine to medium sandstone (core WP-345 depth 346-345 m; 160-159 m below base of Nonesuch Formation). D. Red-brown mudstone with abundant calcite-pseudomorphed evaporite nodules and thin limestone layers (core JBY-002 depth 199-198 m; 71-70 m below base of Nonesuch Formation). E. Tepee and caliche fabrics in fine sandstone (core WP-345 depth $363 \mathrm{~m} ; 176 \mathrm{~m}$ below base of Nonesuch Formation). F. Close up of chicken-wire fabric in C. G. Caliche in fine sandstone (core WP-345 depth 326 m; 139 m below base of Nonesuch Formation). H. Gypsum layers (marked by arrows) in red-brown fine sandstone (core CW-09-95 depth c. 131 m or 433'; lower layer is $18 \mathrm{~cm}$ below base of Nonesuch Formation). White bars are c. $10 \mathrm{~mm}$ for scale.

Figure 12. Desiccation cracks in the Nonesuch Formation. A. $1 \mathrm{~m}$ above base of Big Iron River section. B. $161 \mathrm{~m}$ above base of Big Iron River section. C. $45 \mathrm{~m}$ above base of Formation in core JBY-002 (core depth $81.5 \mathrm{~m}$ ). D. $0.5 \mathrm{~m}$ above base of Formation in core WP-299 (core depth 250.7 m). E. $39 \mathrm{~m}$ above base of Formation in core JBY-022 (core depth $88.2 \mathrm{~m}$ ). F. $20 \mathrm{~m}$ above base of Big Iron River section.

Figure 13. Microbial laminae and structures in the Nonesuch Formation. A. Black crinkle-wrinkle laminae $3 \mathrm{~m}$ above base of Formation in core WP-299 (core depth of $250.7 \mathrm{~m}$ ); note rip-up flakes of microbial laminae in the overlying lighter grey mudstone. White bar c. $10 \mathrm{~mm}$ for scale. B.

Elephant-skin textured bedding surface $17 \mathrm{~m}$ above base of Big Iron River section. 
Figure 14. Tide-influenced sedimentary structures in the Nonesuch Formation. A. Repetitive sets of flaser, linsen and pin-stripe bedding $27 \mathrm{~m}$ above base of Formation in Potato River section. B. Line drawing of boxed area in A showing the bimodal sediment transport directions (black arrows) in ripple cross-lamination and reactivation surfaces. C. Flaser bedding with bimodal (herring-bone) ripple cross lamination $164 \mathrm{~m}$ above base of Formation in core WP-551 (core depth $430 \mathrm{~m}$ ); white bar is c. $10 \mathrm{~mm}$ for scale. D. Line drawing of C. E. Combined-flow ripples with mud drapes and reactivation surfaces $57.5 \mathrm{~m}$ above base of Big Iron River section.

Figure 15. Shelf-shoreline sedimentary structures in the Nonesuch Formation. A. Metre-scale hummocky cross-stratification (hammer at crestline for scale); Presque Isle section $4 \mathrm{~m}$ below base of Freda Formation. B. Many-metres-thick thickening- and coarsening-upward cycles composed of interbedded mudstone and flaser-linsen-combined-flow rippled siltstones and fine sandstones upward into flat-laminated medium sandstone (Bonanza Falls $138 \mathrm{~m}$ above base of Big Iron River section). C. Flat to low-angle laminated sandstone that mark the top of thickening and coarseningupward cycles (this is the uppermost sandstone bed shown in B). D. Sharp-based oolitic-lithic grainstone-packstone (core JBY-002 depth 120 m; 7 m above base Nonesuch Formation).

Figure 16. Fabrics and textures of former Ca-sulphate evaporites in the Nonesuch Formation. A. Sharp contact (marked by arrow) of basal black shale of Nonesuch Formation on red-brown mudstone of Copper Harbor Formation; calcite-pseudomorphed evaporite nodules and pellets are present within both formations with inset photo highlighting those in the basal Nonesuch Formation (core JBY-002 depth 127 m; base Nonesuch Formation). B. Interbedded polylithic caliche with red-brown, grey and black mudstone/shale containing calcite-pseudomorphed evaporite nodules (core JBY-002 depth 118-16 m; 9-11 m above base Nonesuch Formation). C. Close-up of polylithic caliche and underlying black shale with calcite-replaced evaporite layers in B. D. Calcite pseudomorphed evaporite nodules in red-grey mudstone and in desiccation crack (core JBY-002 depth 113 m; 14 m above base Nonesuch Formation). E. Marker Bed showing laminated grey shale with stringers of calcite-pseudomorphed evaporite blebs ( $17.5 \mathrm{~m}$ above base Nonesuch Formation Big Iron River section). F. Stringers of calcite-pseudomorphed evaporite blebs in black shale (core JBY-002 depth 72 m; 55 m above base Nonesuch Formation). G. Interbedded redbrown and dark grey mudstone with the latter containing abundant calcite-pseudomorphed evaporite blebs (core JBY-002 depth 97 m; 30 m above base Nonesuch Formation. H. Calcitepseudomorphed former evaporite laths in red-brown mudstone (core JBY-002 depth $109 \mathrm{~m} ; 18 \mathrm{~m}$ above base Nonesuch Formation). White bar in photos is c. $10 \mathrm{~mm}$ for scale.

\section{Tables}

Table 1. (2 column fitting).

\begin{tabular}{|c|c|c|c|c|c|c|c|}
\hline \multirow{2}{*}{ process } & \multirow{2}{*}{ sedimentary feature } & \multicolumn{2}{|c|}{ common } & \multicolumn{2}{|c|}{ may be present } & \multicolumn{2}{|c|}{ rare to not present } \\
\hline & & lacustrine & marine & lacustrine & marine & lacustrine & marine \\
\hline \multirow{3}{*}{ unidirectional } & dm-scale trough $x$-bdg & $\mathrm{x}$ & $\mathrm{x}$ & & & & \\
\hline & dm-scale planar $x$-bdg & $\mathrm{x}$ & $\mathrm{x}$ & & & & \\
\hline & asymmetric ripples & $\mathrm{x}$ & $x$ & & & & \\
\hline
\end{tabular}




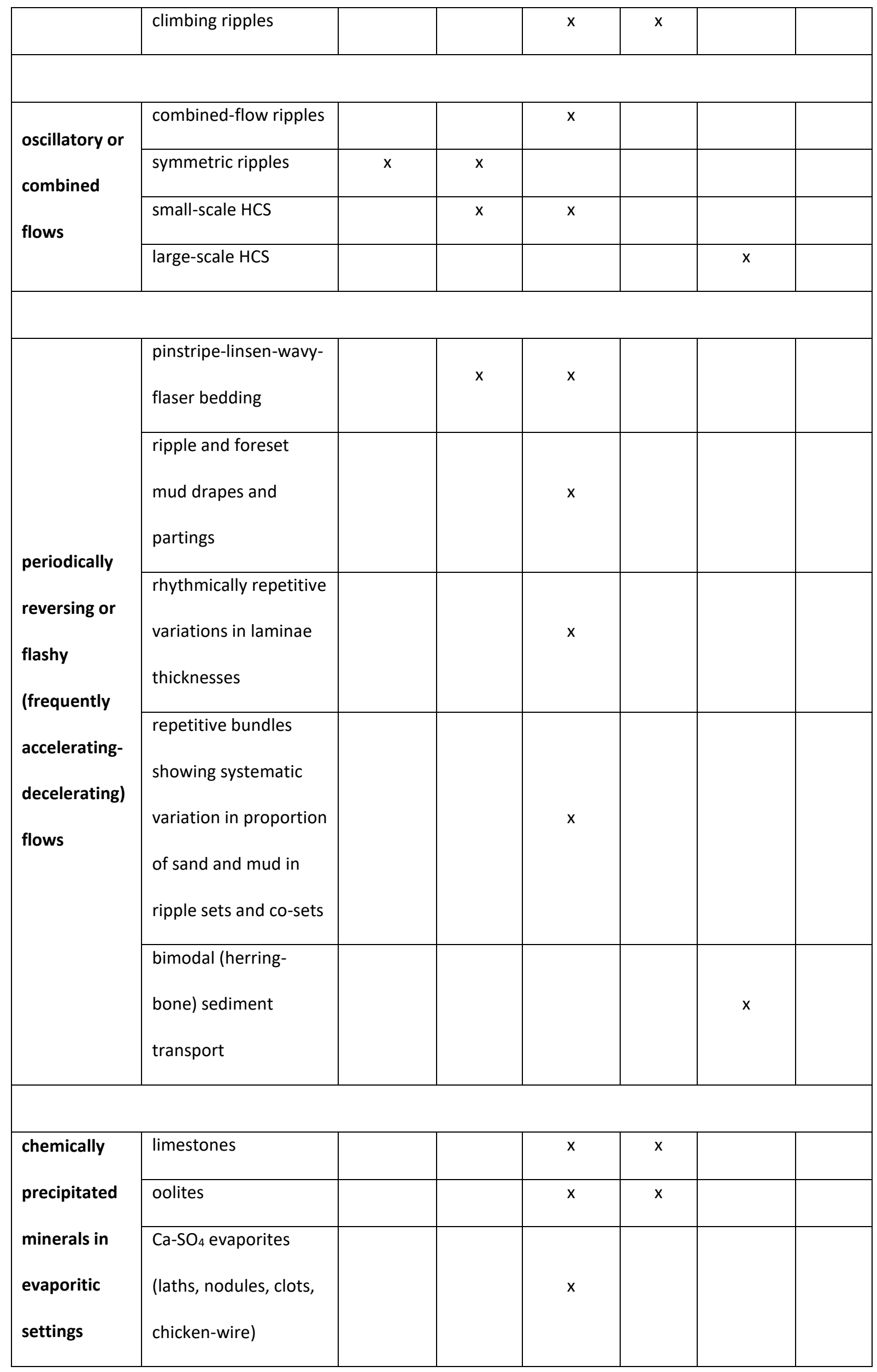




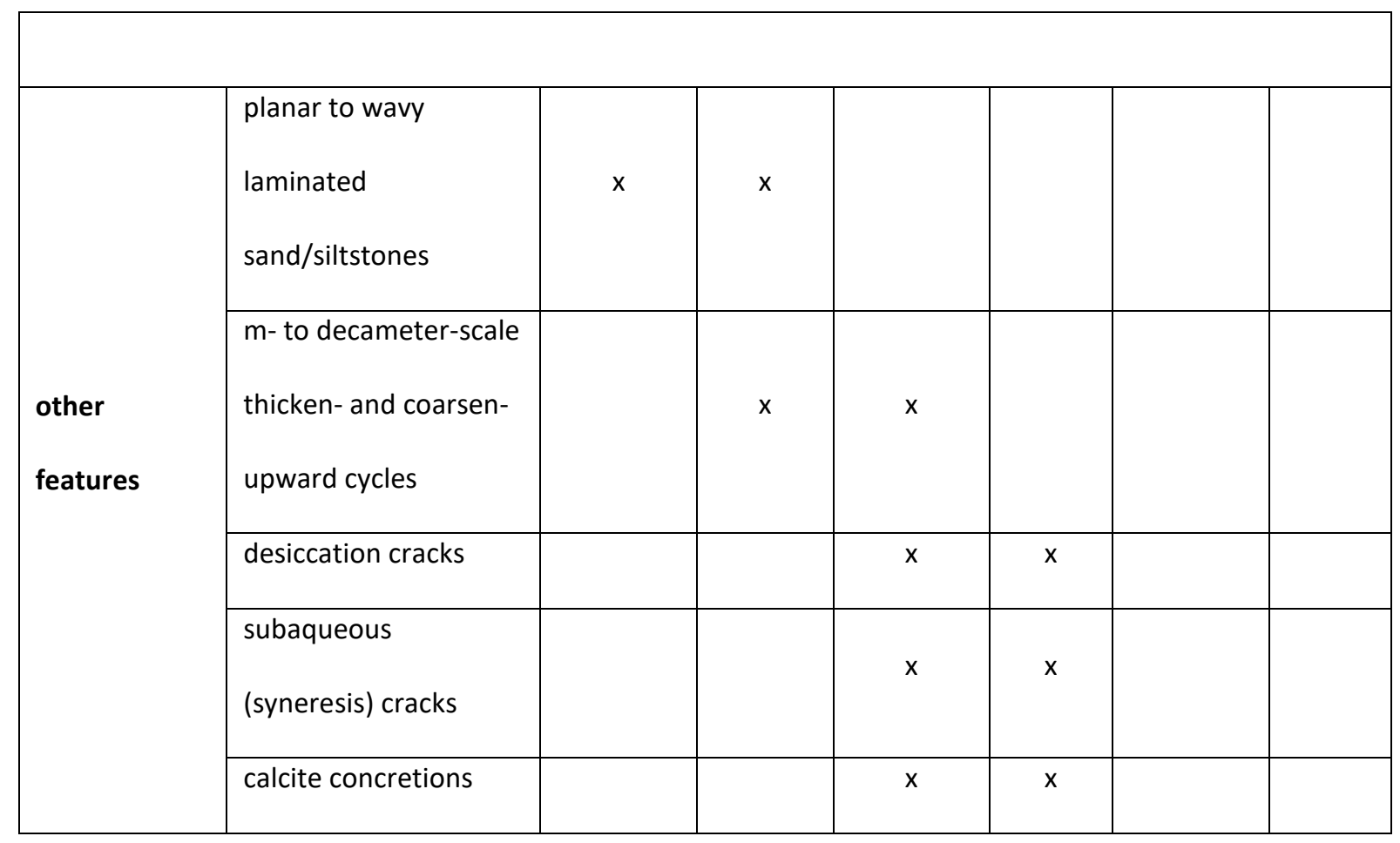




\section{Figures}

Figure 1 . ( 2 column fitting).

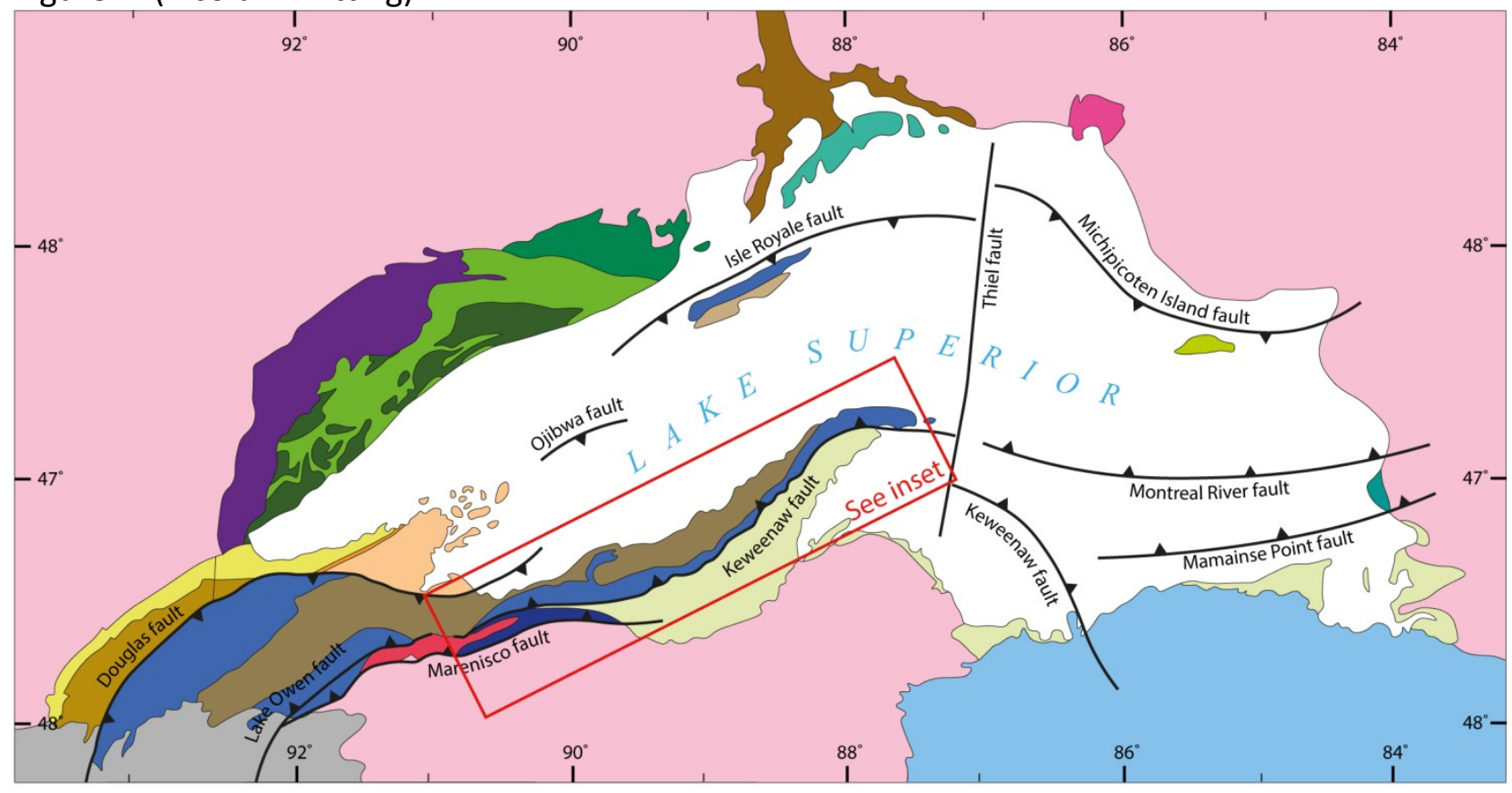

\begin{tabular}{|c|c|}
\hline Osler Volcanics Group & Oronto Group \\
\hline Logan Sills & Bergland Group \\
\hline North Shore Volcanics Group & Mellen Complex \\
\hline Beaver Bay Complex & Powder Mill Group \\
\hline Coldwell Complex & Sibley Group \\
\hline Duluth Complex & Mamainse Point Fm \\
\hline Pre-Mesozoic basement & Michipicoten Island F \\
\hline
\end{tabular}

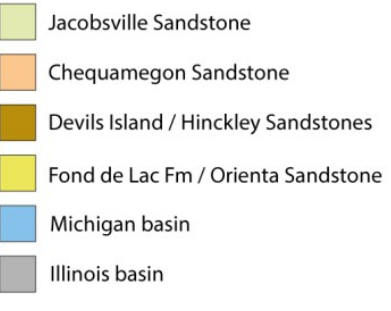

$\frac{\mathrm{U}}{\mathrm{D}}$ Reverse fault

trats

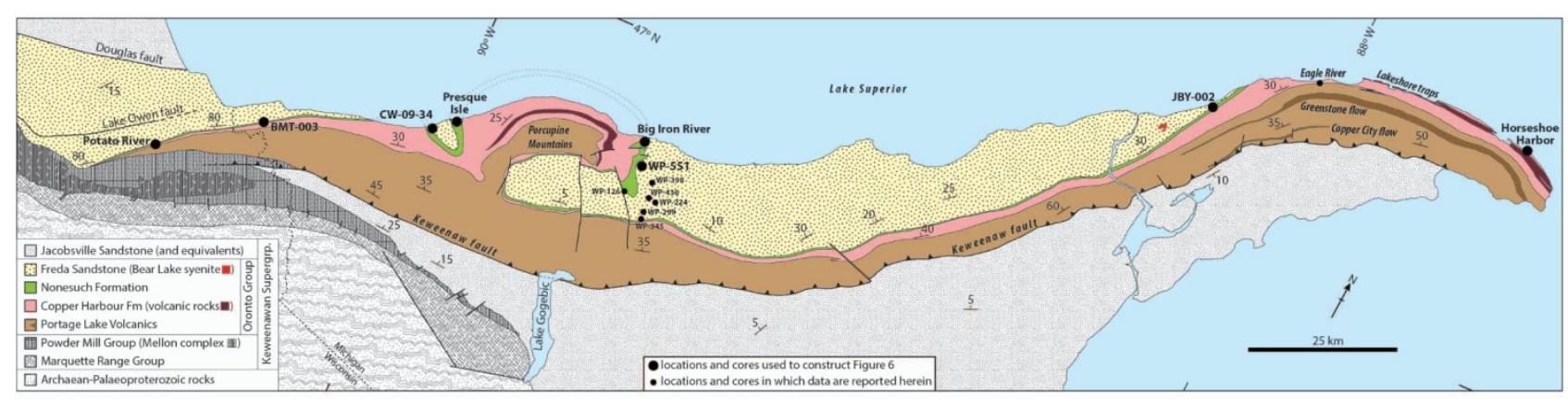


Figure 2. (1 column fitting).

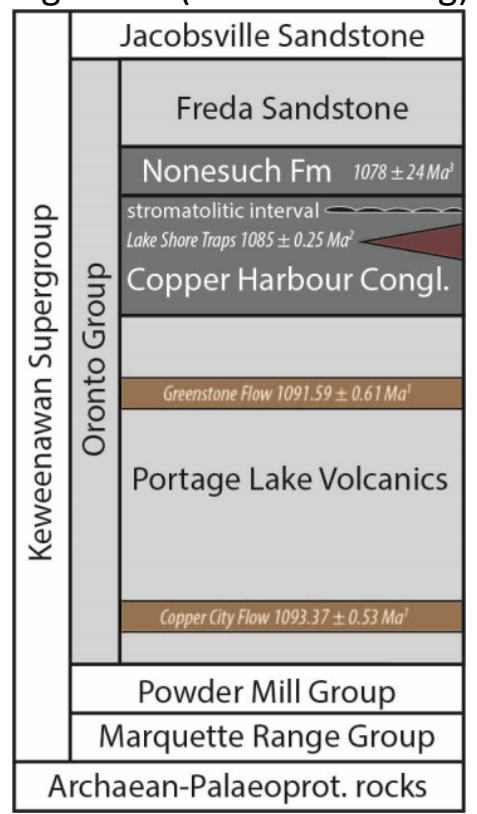


Figure 3. (1.5 column fitting).
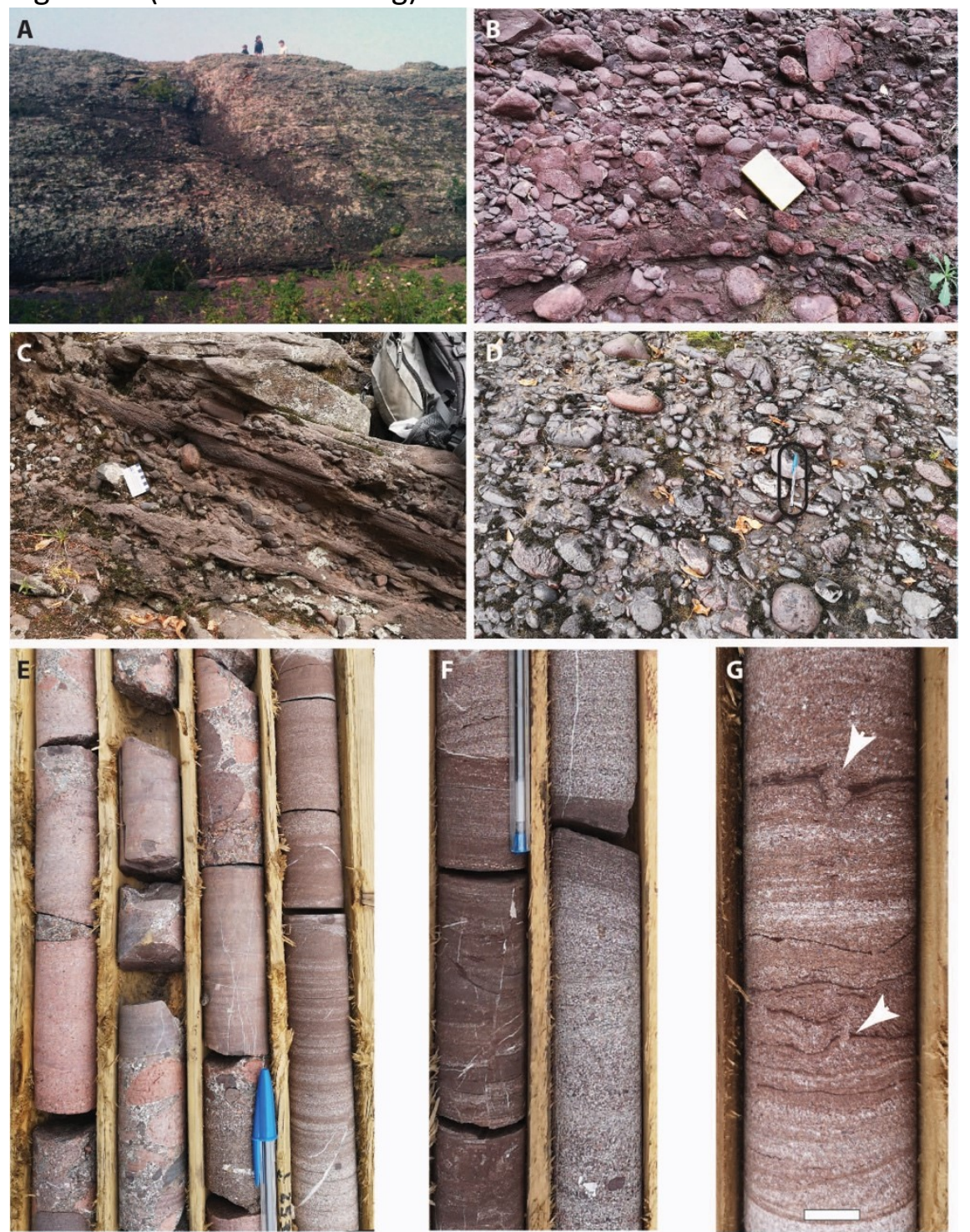
Figure 4. (1.5 column fitting).
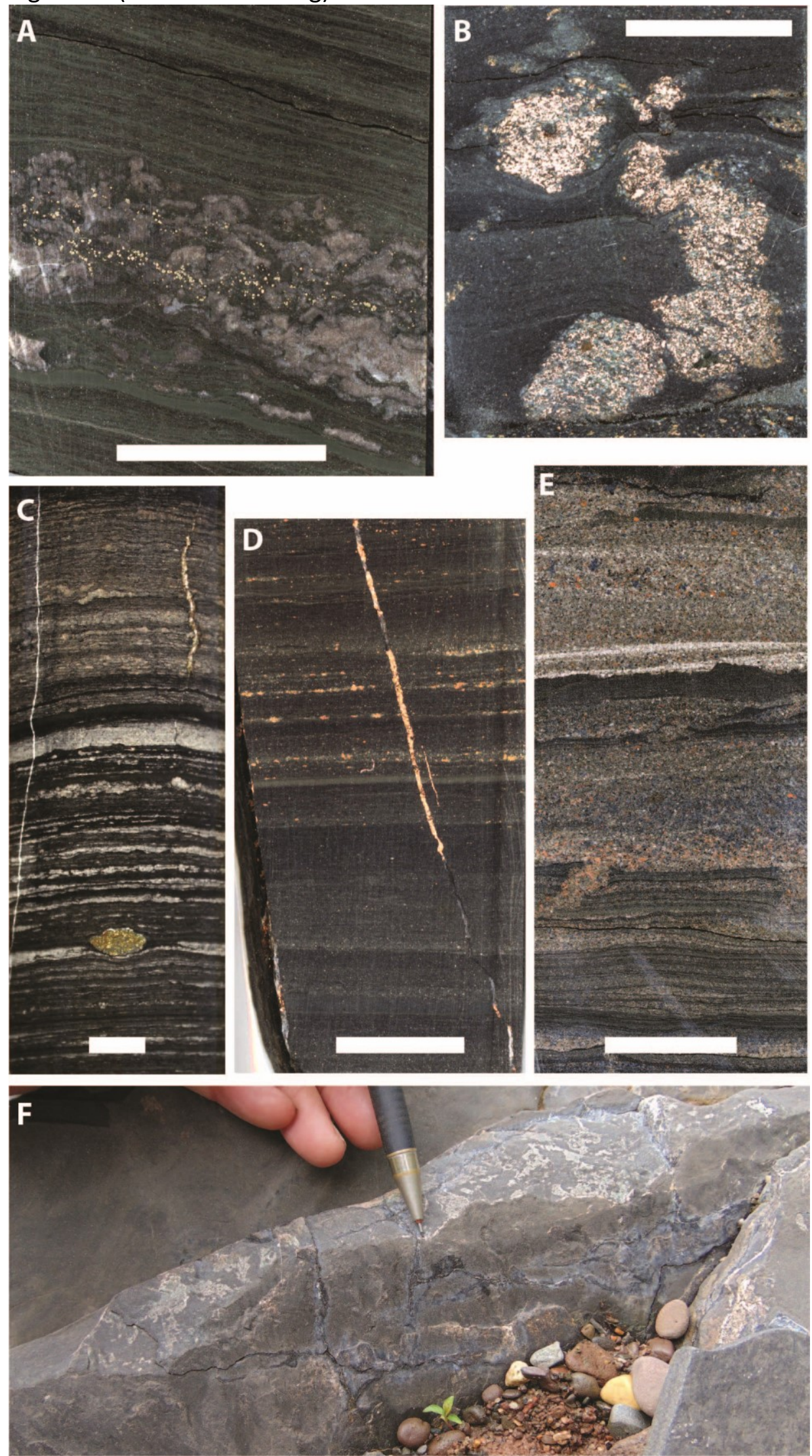
Figure 5. (1.5 column fitting).
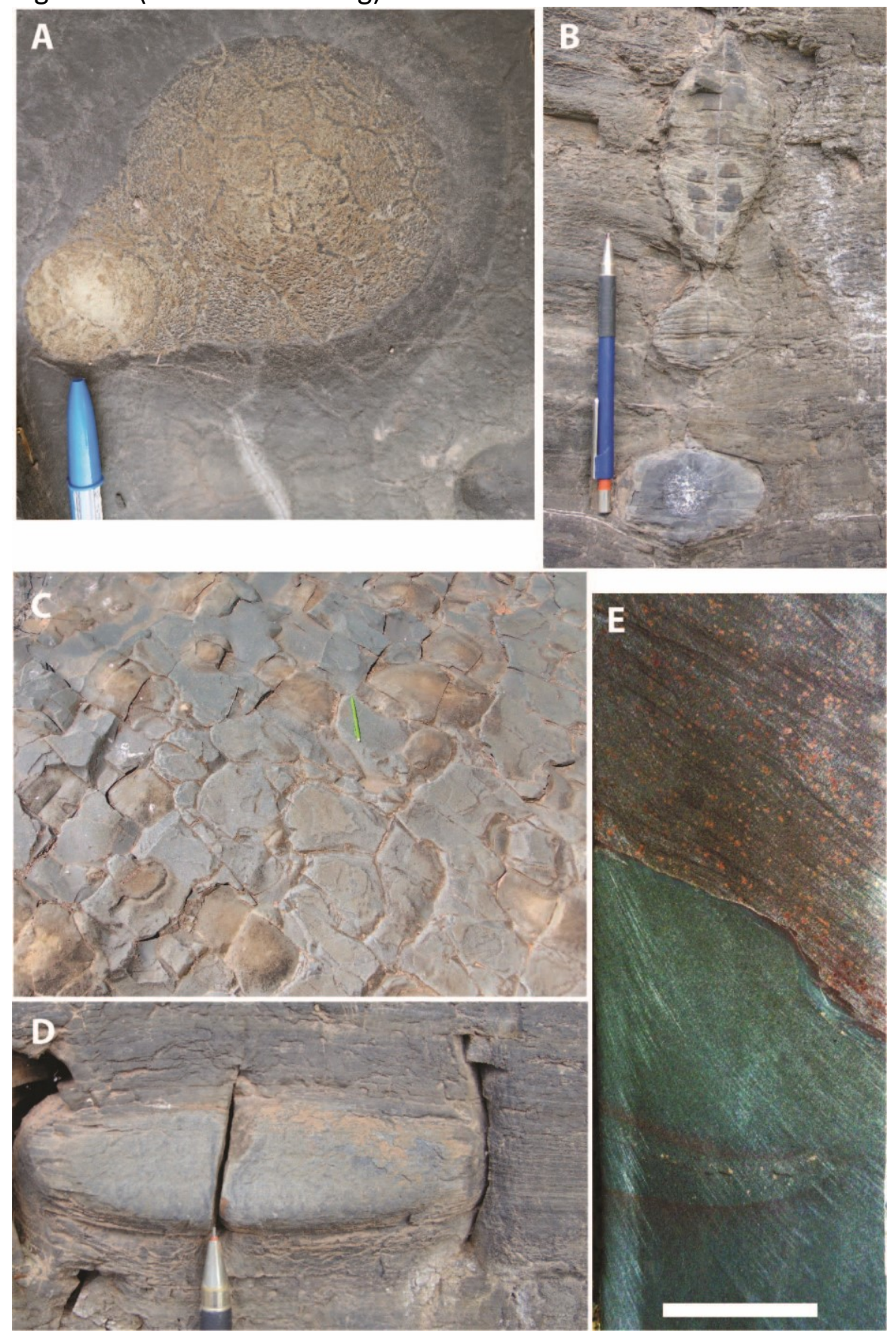
Figure 6. (2 column fitting).
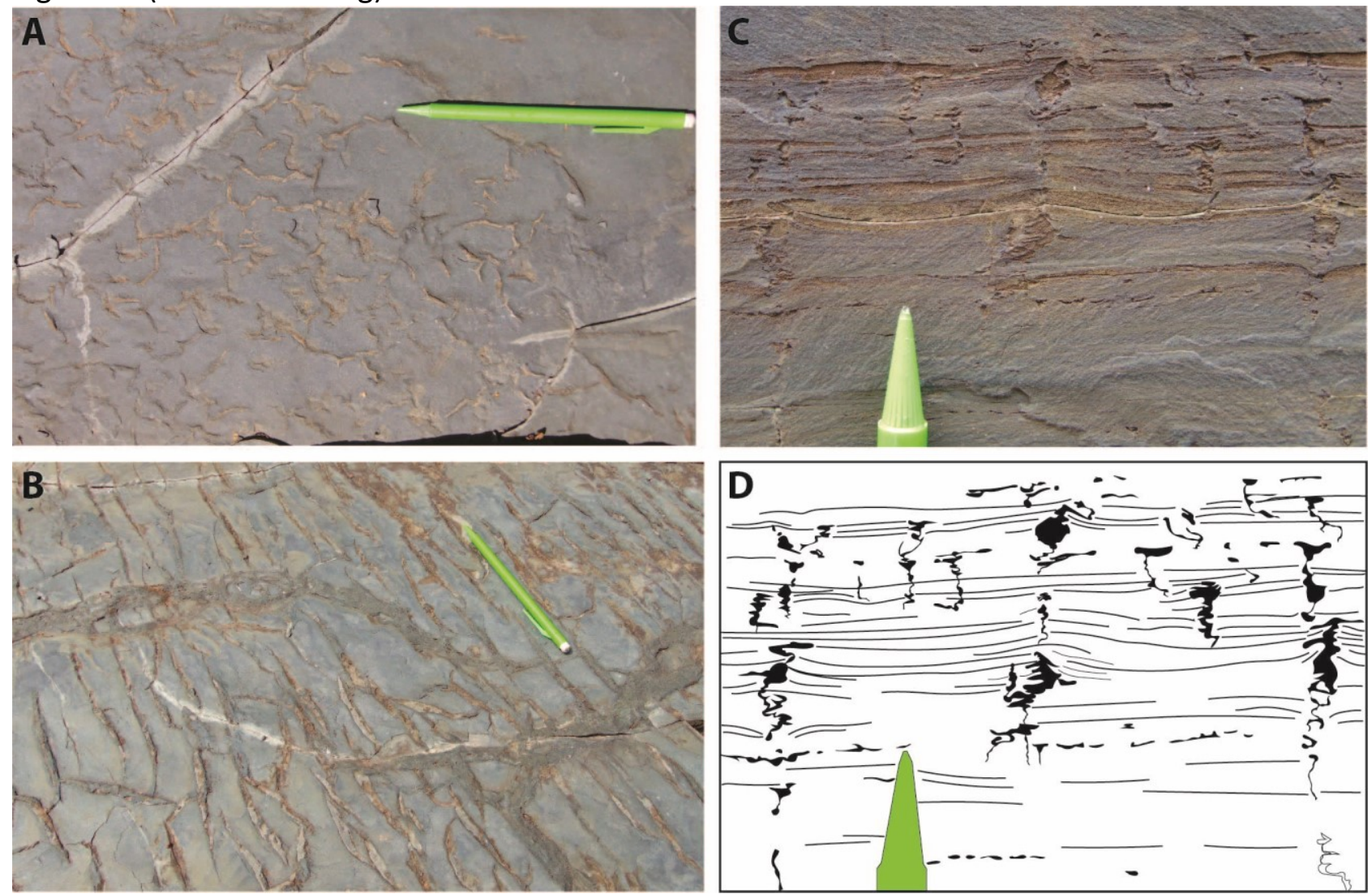
Figure 7. (2 column fitting).

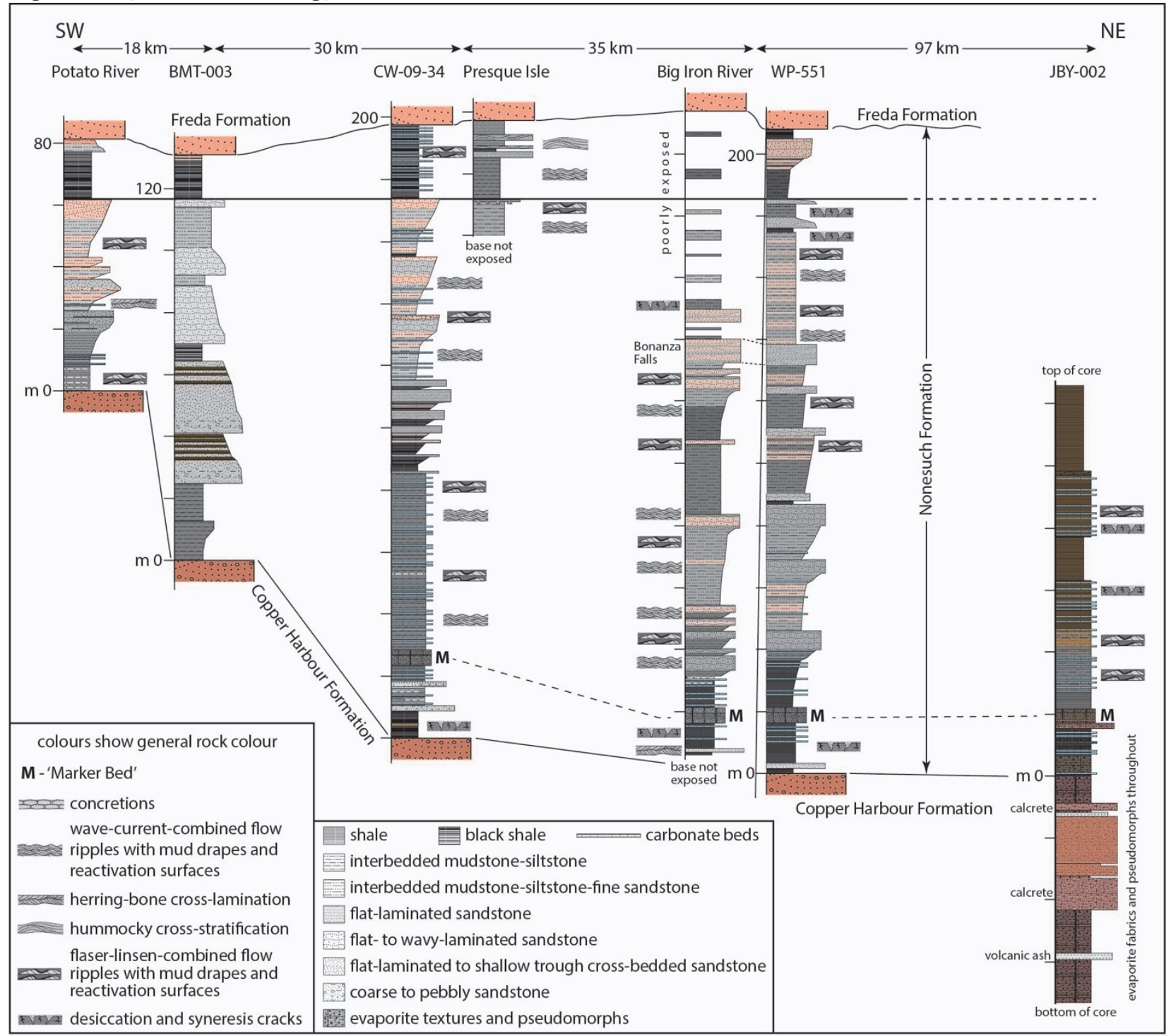

Figure 8. (1 column fitting).

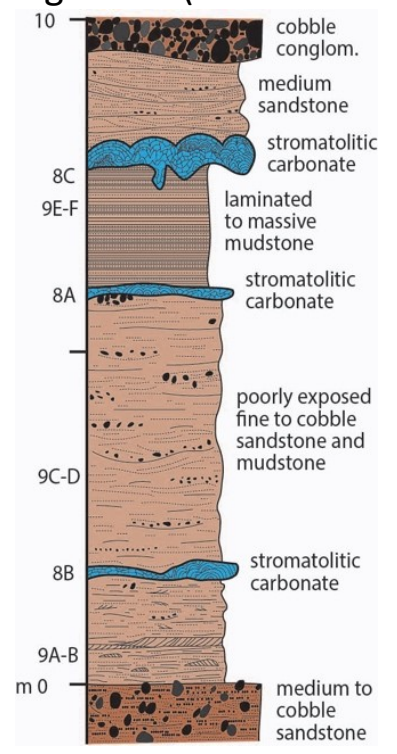


Figure 9. ( 2 column fitting).
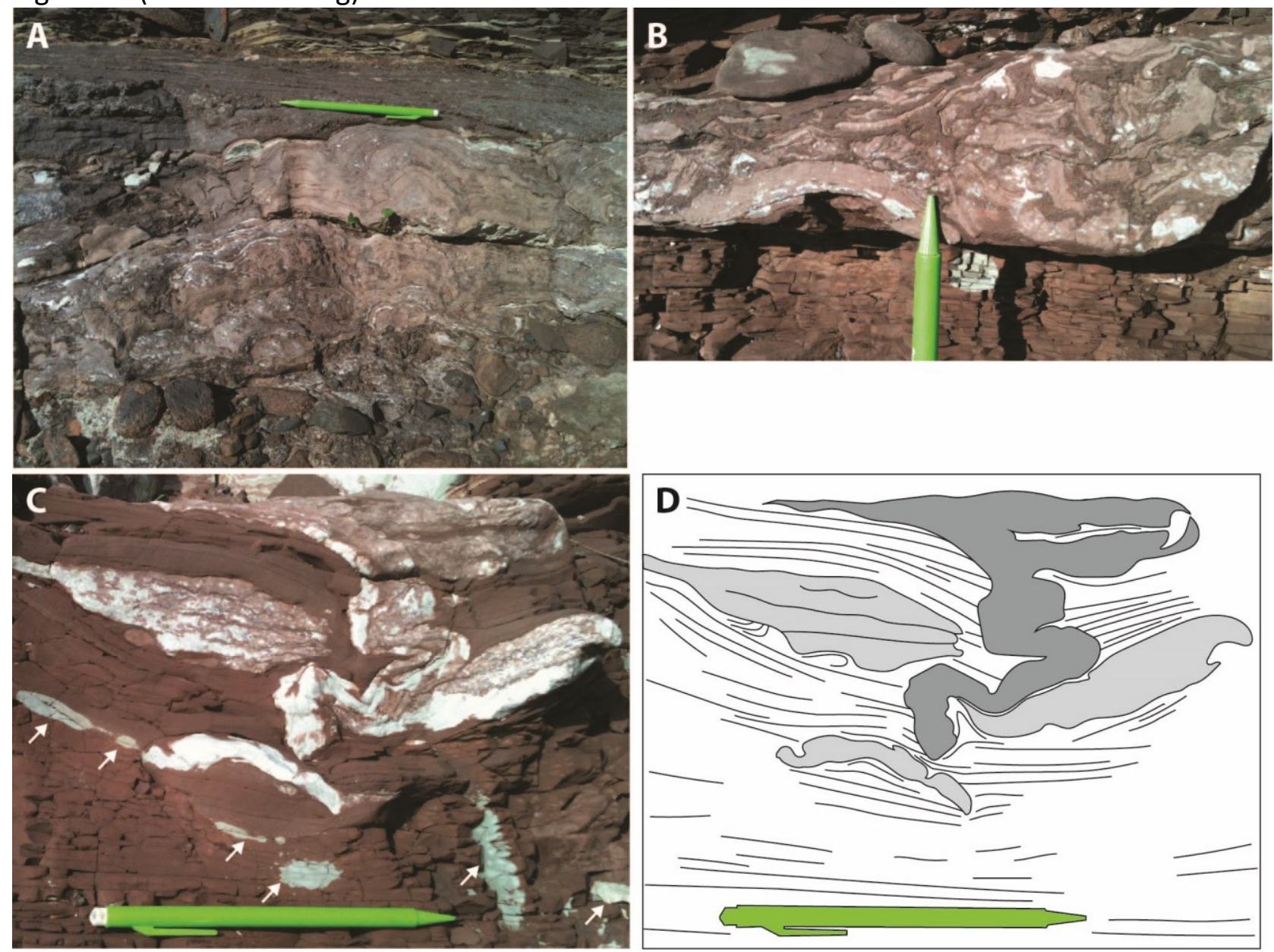
Figure 10. (1.5 column fitting).
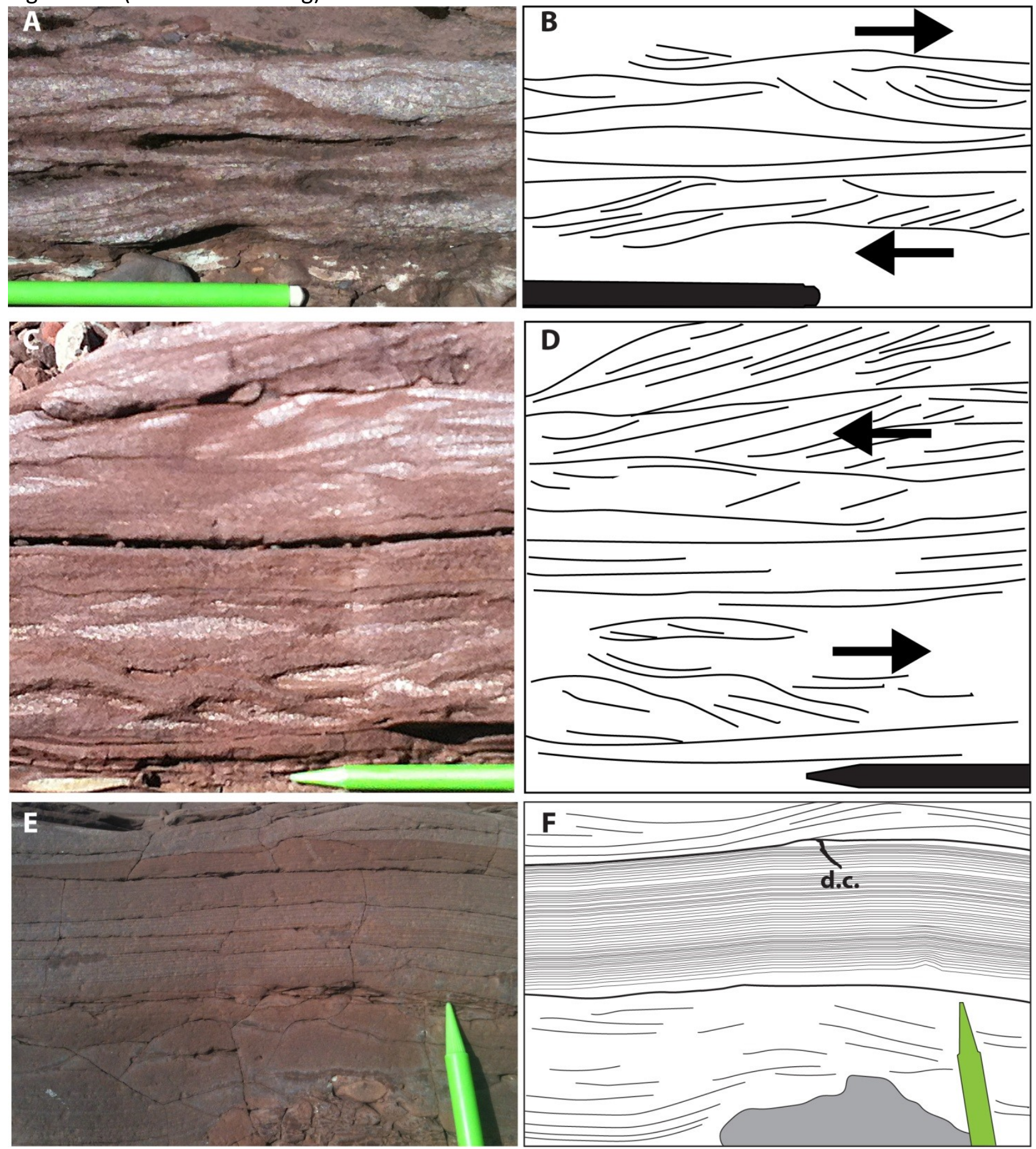
Figure 11 . (1.5 column fitting).
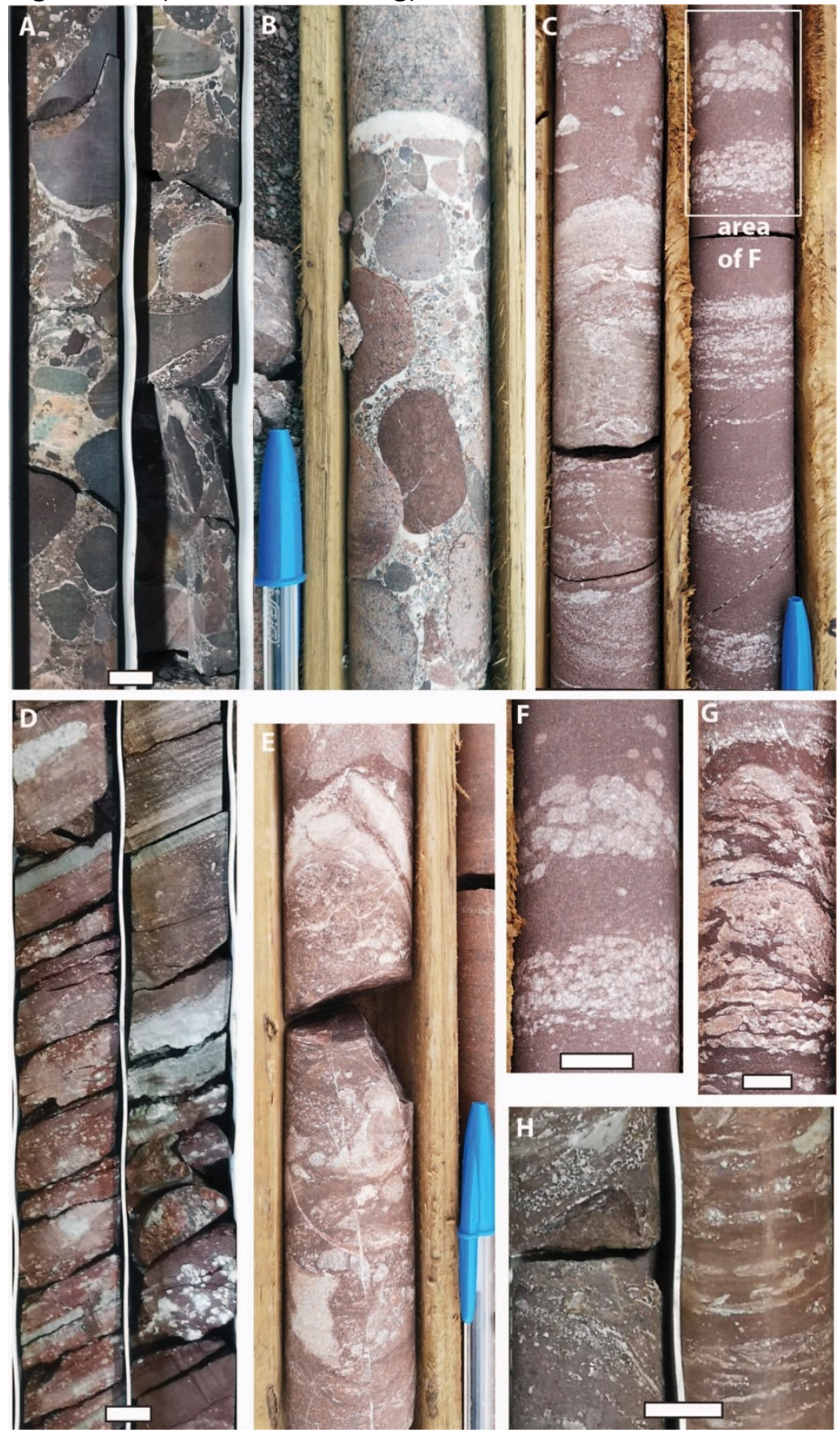
Figure 12. (1.5 column fitting).
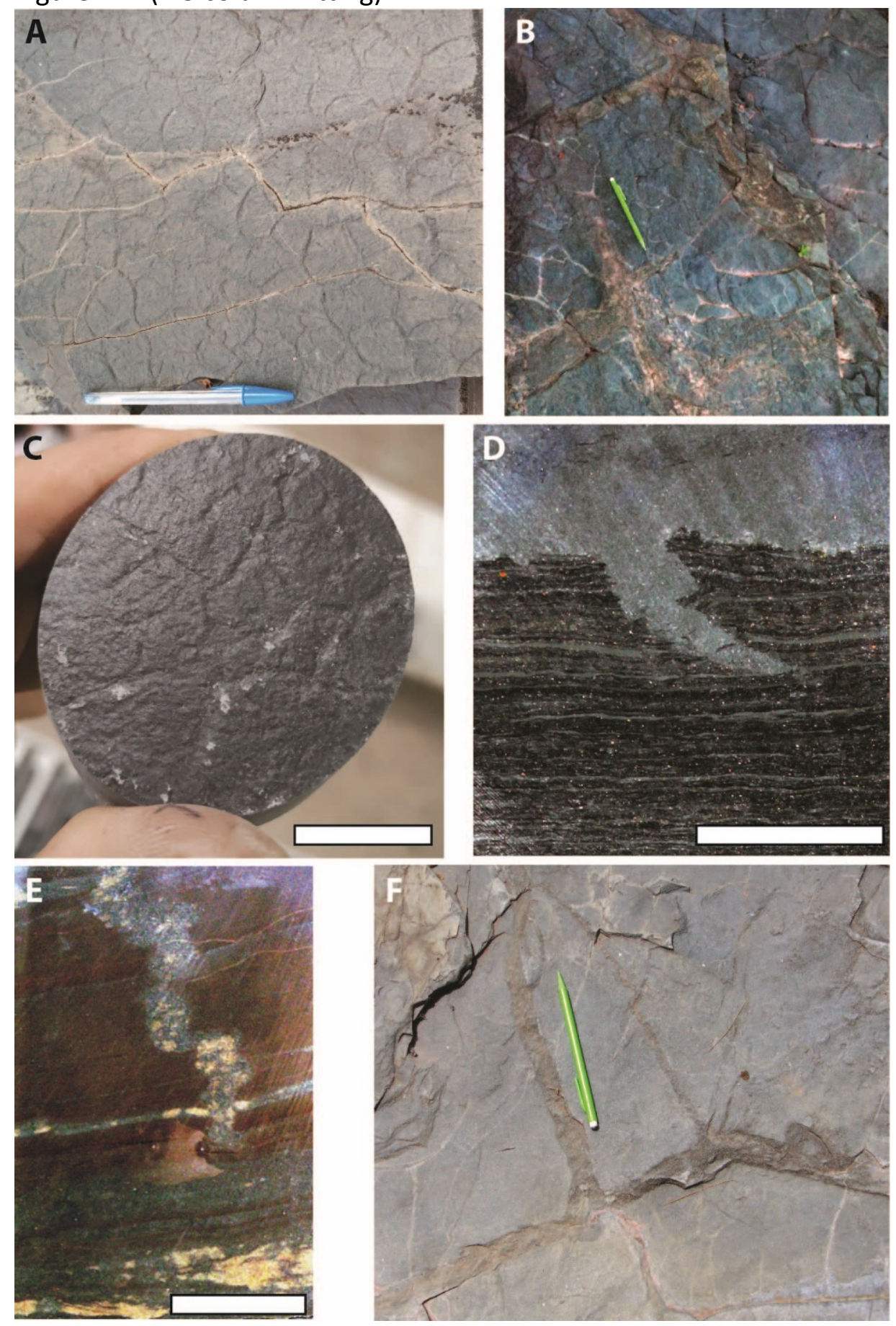
Figure 13. (1.5 column fitting).
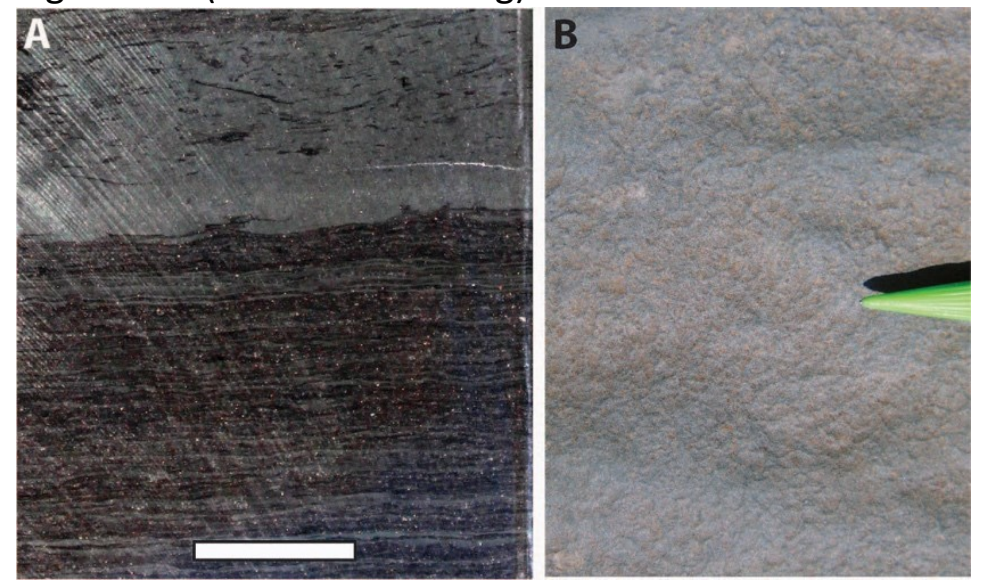

Figure 14. (2 column fitting).
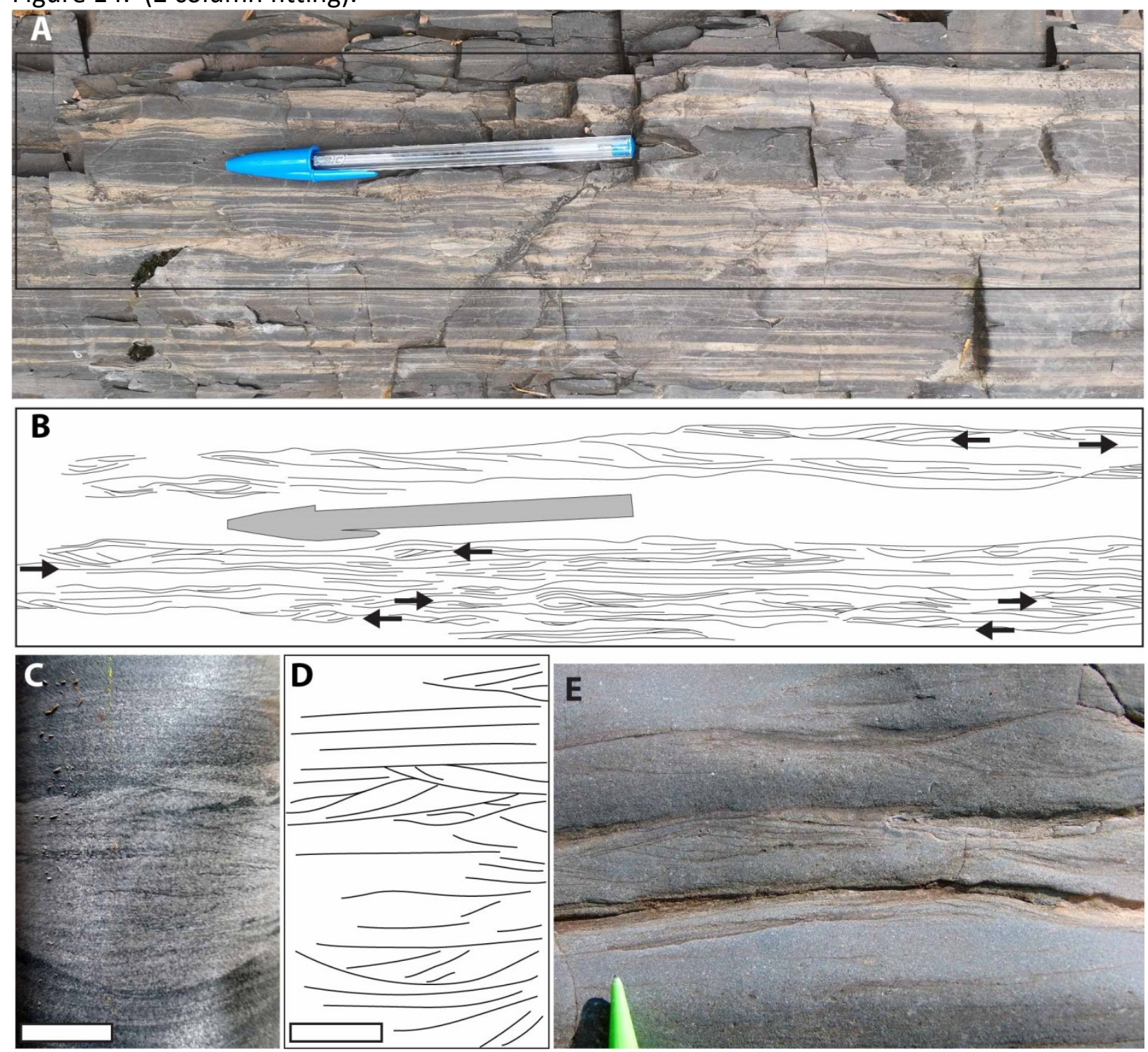
Figure 15 . (1.5 column fitting).
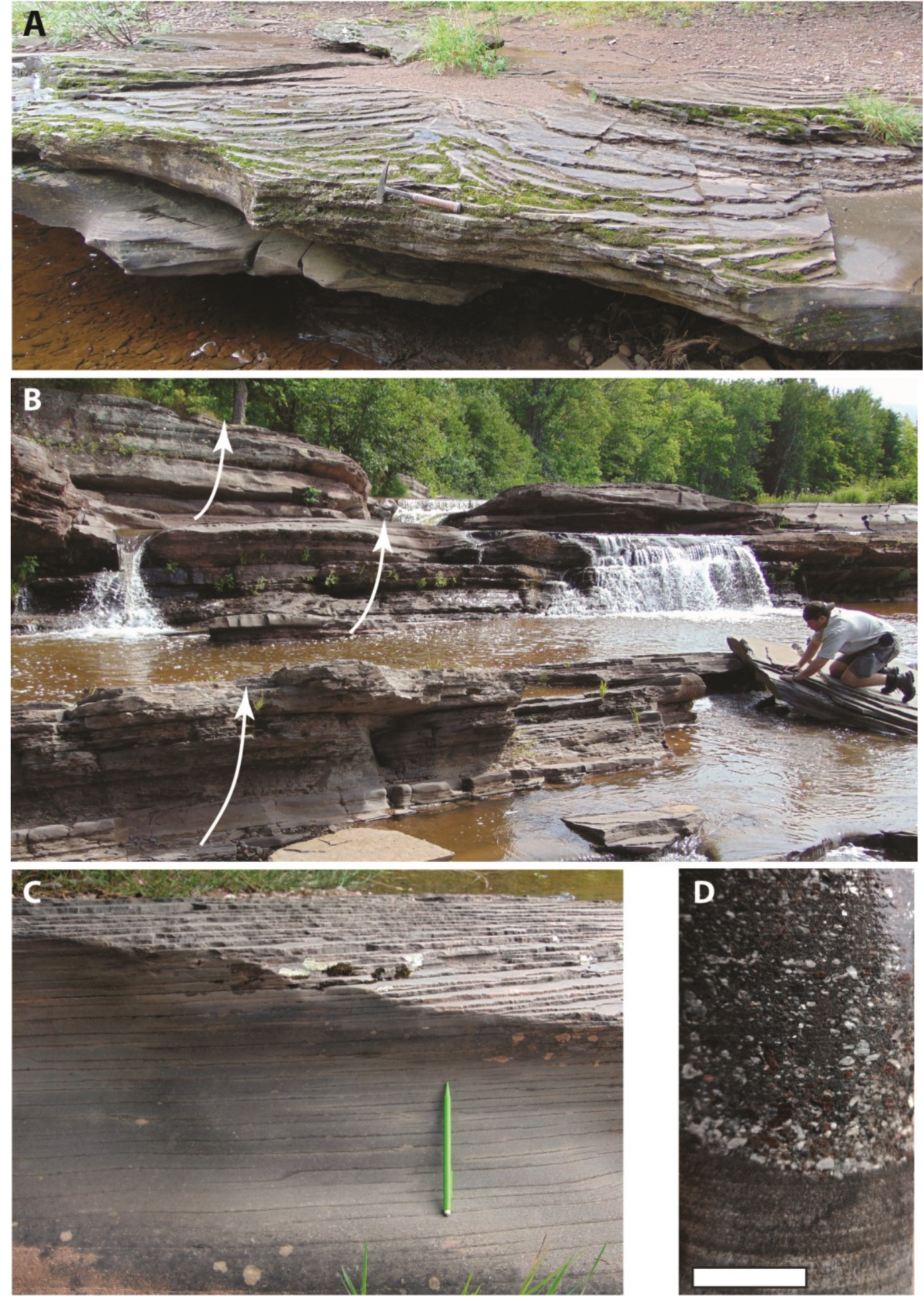
Figure 16. (1.5 column fitting). Separate source file (>10MB).

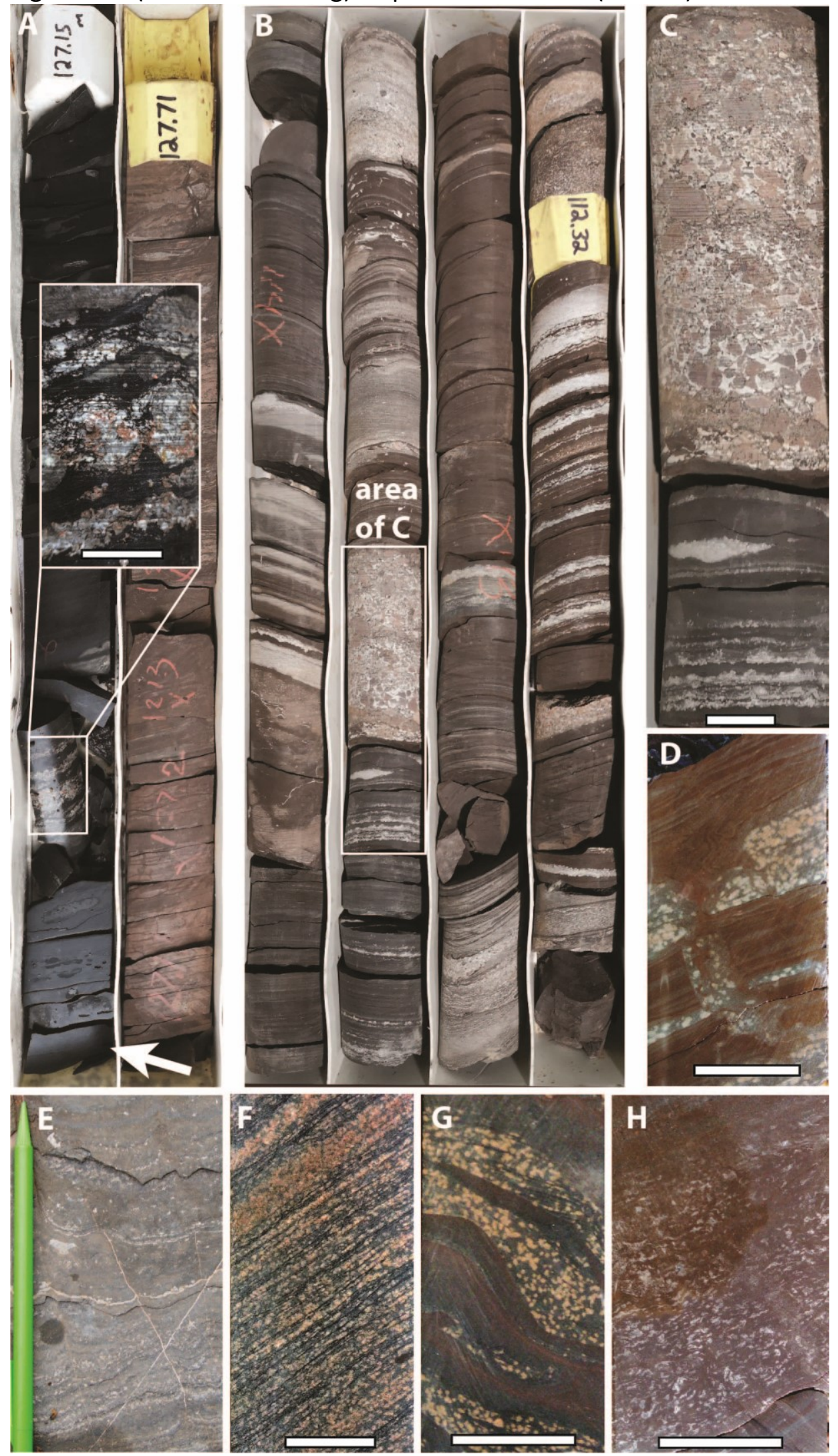

